\title{
Rapeseed meal hydrolysate as substrate for microbial astaxanthin production
}

Article

Accepted Version

Harith, Z. T., Charalampopoulos, D. and Chatzifragkou, A. (2019) Rapeseed meal hydrolysate as substrate for microbial astaxanthin production. Biochemical Engineering Journal, 151. 107330. ISSN 1369-703X doi:

https://doi.org/10.1016/j.bej.2019.107330 Available at https://centaur.reading.ac.uk/85546/

It is advisable to refer to the publisher's version if you intend to cite from the work. See Guidance on citing.

To link to this article DOI: http://dx.doi.org/10.1016/j.bej.2019.107330

Publisher: Elsevier

All outputs in CentAUR are protected by Intellectual Property Rights law, including copyright law. Copyright and IPR is retained by the creators or other copyright holders. Terms and conditions for use of this material are defined in the End User Agreement.

\section{www.reading.ac.uk/centaur}

\section{CentAUR}

Central Archive at the University of Reading 
Reading's research outputs online 
${ }^{a}$ Faculty of Agro Based Industry, Universiti Malaysia Kelantan Jeli Campus, 17600 Jeli, Kelantan, Malaysia

${ }^{\mathrm{b}}$ Department of Food and Nutritional Sciences, University of Reading, Whiteknights, RG6 6AP, Reading, United Kingdom 


\section{Abstract}

2 Rapeseed meal, a by-product of oil processing industry, was evaluated as a substrate for astaxanthin

3 production by the yeast Xanthophyllomyces dendrorhous DSMZ 5626. Four commercial enzymes

4 were tested at different concentrations $(1-15 \%, v / v)$ for their ability to break down the cellulosic

5 and hemicellulosic compounds of rapeseed meal into fermentable sugars. Viscozyme® L and

6 cellulase demonstrated the highest glucose recovery yields $(47-52 \%$, w/w for $15 \%(\mathrm{v} / \mathrm{v})$ of

7 enzyme loading) with 7- $11 \mathrm{~g} / \mathrm{l}$ of net glucose released in the hydrolysates. Pectinase and

8 Accellerase ${ }^{\circledR}$ hydrolysates supported the best cell growth and astaxanthin production in batch shake

9 flask cultures, with maximum biomass of $26 \mathrm{~g} / \mathrm{l}$ and $15 \mathrm{~g} / \mathrm{l}$, respectively, and astaxanthin yields

10 (Y $\mathrm{P} / \mathrm{X})$ of 258 to $332 \mu \mathrm{g}$ per g of biomass. In batch bioreactor trials, pectinase hydrolysates resulted

11 in high biomass (42 g/l) and astaxanthin production $(11 \mathrm{mg} / \mathrm{l})$ aided by the presence of glycerol

12 (originating from the enzyme formulation) which served as additional energy and carbon source.

13 Finally, simple glass beads disruption lead into satisfactory astaxanthin extraction (95\%, w/w) in

14 acetone. The findings of this study generate knowledge towards scale-up potential of microbial

15 astaxanthin production using rapeseed meal hydrolysate as fermentation feedstock.

17 Keywords: Astaxanthin, rapeseed meal, fermentation, hydrolysate, extraction, Xanthophyllomyces 18 dendrorhous 
Oilseed crops, such as rapeseed, sunflower and soybean, are extensively cultivated for their oil. The European Union (EU) is the largest producer of rapeseed with a reported total production of 32 million tonnes in 2015/16 and these figures are expected to increase annually [1]. In the United Kingdom (UK), rapeseed (Brassica napus) is a major oilseed crop, which is cultivated alongside sunflower with a reported total of $579 \mathrm{kHa}$ of land planted in 2016 [2].

The oil extraction process leaves behind a solid residue, known as rapeseed meal, which is generally underutilised and considered as a low value by-product [3]. The world production of rapeseed meal in 2016/17 was estimated at 40 million tonnes, with 13.9 million tonnes generated in

10 the EU [1], a rise linked with intense rapeseed farming to meet the increasing demand for vegetable

11 oils. This in turn suggests that opportunities still exist for developing alternative uses for rapeseed meal beyond animal feed [4]. Currently, rapeseed meal is used as an organic fertiliser and as a

13 supplement in livestock feed due to its high protein content $(26-31 \%)[5,6]$. However, its protein is 14 not easily digested by monogastric animals compared to other protein sources such as soy meal, 15 thus rendering it less valuable as a feed component [7]. Moreover, rapeseed meal may contain anti16 nutritional compounds such as glucosinolates, erucic acid and phenols, thus making it less 17 favourable for livestock $[4,8]$.

There is significant potential for the valorisation of rapeseed meal, particularly as a substrate

19 for microbial bioconversions, since besides protein, it also contains large amounts of carbohydrates $(36-36 \%, w / w)[6,9]$ as well as minerals such as calcium, phosphorous and iron $[6,10]$. The 21 utilisation of rapeseed meal in microbial bioconversions is not a single step process, since most 22 microorganisms lack the necessary enzymes for cellulose/hemicellulose hydrolysis. As such, the 23 transformation of rapeseed meal into a fermentation feedstock requires the application of 24 physicochemical and/or enzymatic approaches, aiming to break down the complex structure of the 25 biomass and concurrently generate sugar and nitrogen components that are directly assimilable by 
1 microorganisms [7,10]. The rapeseed meal hydrolysates can be potentially used for several

2 microbial conversions, including the production of platform and speciality chemicals such as

3 succinic acid [11], 1,3-propanediol [10], biopolymers (poly-hydroxy-alkanoates)[12] and lipids [7].

Astaxanthin belongs to the xanthophyll group of carotenoids and is a powerful antioxidant, which acts by donating electrons from the conjugated double bonds and reacts with free radicals to produce high stability products and terminate the free radical chain reaction in a wide range of living organisms [13]. The application of an external source of antioxidants such as astaxanthin is necessary for human body to regulate the free radicals and suppress the occurrence of oxidative stress which subsequently can alter lipids, proteins and DNA, as well as trigger human diseases [14]. Astaxanthin also possesses anti-inflammatory activities and has potential as a therapeutic

11 agent against cardiovascular diseases in humans [15]. Additionally, astaxanthin is used in 12 aquaculture as feed additive because it contributes to the attractive colouration in the bodies of 13 salmons, shrimps and crustaceans as well as maintains their growth and survival [16,17]. Currently, 14 the commercial demand for astaxanthin is met by its synthetic production (petroleum derived) via the Wittig reaction and Grignard condensation methods [18]. However, natural astaxanthin is more favourable as it has been reported to possess high stability due to its esterified nature, which prevents oxidation and thus exhibits prolonged shelf life [19]. The natural source of astaxanthin has been approved to be used as food colouring (E161j) in the EU. Currently, the naturally produced astaxanthin by microalgae (Haematococcus pluvialis) and yeasts (Xanthophyllomyces dendrorhous) face a competitive market price compared to synthetically produced astaxanthin due to their complex production process. The value of natural astaxanthin is estimated around USD 2500-7000 per $\mathrm{kg}$, depending on its purity, as opposed to the value of synthetically-produced astaxanthin, which is estimated around USD 2000 per $\mathrm{kg}[20,21]$.

Studies aiming to extract rapeseed protein have been conducted using various methods such as commercial cellulolytic enzymes [22] as well as the use of the proteolytic fungus, Aspergillus oryzae [10]. However, studies involving carbohydrates hydrolysis from rapeseed meal are scarce in 
1 comparison to protein hydrolysis [22,23]. Thus, the aim of this study was to enzymatically

2 hydrolyse the lignocellulosic components of rapeseed meal and produce a nutrient-rich hydrolysate,

3 which was subsequently evaluated as a fermentation substrate for astaxanthin production by the

4 yeast $X$. dendrorhous DSMZ 5626. In addition, the application of glass beads was investigated as a

5 simple method for the extraction of intracellular astaxanthin from yeast cells.

\section{Materials and Methodology}

\subsection{Microorganism and Growth Medium}

The yeast strain Xanthophyllomyces dendrorhous DSMZ 5626 was used in this study and was

10 purchased from the Leibniz Institute DSMZ, Germany. The strain was proliferated and maintained

11 in Yeast and Mold (YM) media containing (in g/L): yeast extract, (3.0); malt extract, (3.0); peptone

12 from soybean, (5.0); glucose, (10.0); and agar (15).

\subsection{Materials}

The rapeseed meal used in this study was kindly provided by Stainswick Farm (Oxfordshire,

15 UK) and was generated via cold pressing oil extraction process. Rapeseed meal samples were 16 grinded using a dry-grinder and sieved to obtain uniform sized particles $(<850 \mu \mathrm{m})$. The remaining

17 oil in the meal was removed using a supercritical $\mathrm{CO}_{2}$ extraction rig (SciMed, UK) at $60{ }^{\circ} \mathrm{C}$ and 300

18 bar pressure for $1 \mathrm{~h}$, with ethanol $(10 \%, \mathrm{v} / \mathrm{v})$ as co-solvent. The residual defatted meal was kept at 4 $19{ }^{\circ} \mathrm{C}$ prior to use.

\subsection{Enzymatic Hydrolysis}

Enzymatic hydrolysis of rapeseed meal was performed using four different commercial enzymes, namely Accellerase ${ }^{\circledR} 1500$ (DuPont), Viscozyme ${ }^{\circledR}$ (Novozymes), cellulase from 
1 carried out in $2 \mathrm{ml}$ Eppendorf tubes containing $0.150 \mathrm{~g}$ rapeseed meal with different enzyme

2 concentrations $(1-15 \%, \mathrm{v} / \mathrm{v})$. Distilled water was used to make up the volume to $1.5 \mathrm{ml}$. Optimum

3 temperatures for each enzyme and adequate mixing (1600 rpm) were maintained in a thermomixer

$4 \quad \mathrm{~F} 1.5$ (Eppendorf, Germany). The reaction time varied from $2 \mathrm{~h}$ to $24 \mathrm{~h}$ and the reactions were

5 terminated by incubation at $95{ }^{\circ} \mathrm{C}$ for $10 \mathrm{~min}$. The mixtures were then centrifuged at $10845 \times \mathrm{g}$

6 (Heraeus Multifuge X3R, Thermo Fisher, USA) for 10 min and the supernatants were collected and

7 analysed for sugar composition using HPLC as described in section 2.7. The schematic diagram of

8 the experimental procedure is illustrated in Figure 1.

\section{$9 \quad 2.4 \quad$ Rapeseed meal pre-treatment}

The thermal pre-treatment of rapeseed meal was carried out prior to enzymatic hydrolysis

11 using the commercial enzyme Accellerase $1500 \circledR .10 \%(\mathrm{w} / \mathrm{v})$ of rapeseed meal were added to $30 \mathrm{ml}$

12 of distilled water and subjected to autoclaving at different temperatures $\left(126\right.$ and $135{ }^{\circ} \mathrm{C}$, pressure

$13 \sim 2$ bar) for 15,30 or 60 min. Once the heat treatment was completed, $10 \%(\mathrm{v} / \mathrm{v})$ of enzyme was

14 added to the mixture and hydrolysis was carried out at $50{ }^{\circ} \mathrm{C}$ for $24 \mathrm{~h}$ under continuous stirring (250

$15 \mathrm{rpm}$ ) in an orbital shaker (GFL, 3015, SciQuip, UK).

\section{$16 \quad 2.5 \quad$ Microbial Fermentations}

\subsubsection{Shake flask fermentation}

In order to investigate the suitability of rapeseed meal hydrolysates as substrates for $X$.

19 dendrorhous growth, batch shake flask experiments were conducted. Rapeseed meal hydrolysates

20 were prepared using different enzymes under identified optimised conditions. In one case, rapeseed

21 meal was thermally pre-treated, by autoclaving at $126^{\circ} \mathrm{C}$ for 30 min prior to enzyme addition ( $10 \%$,

$22 \mathrm{v} / \mathrm{v}$ of Acellerase $®$ 1500). The produced hydrolysates were subsequently filter-sterilised using 0.25

$23 \mu \mathrm{m}$ Millipore stericup filters, prior to the fermentation. Suspensions of $X$. dendrorhous pre-cultures

24 were then aseptically added to the $50 \mathrm{ml}$ of hydrolysates in $250 \mathrm{ml}$ conical flasks to obtain an initial 
1 OD of $\sim 0.1$. All flask fermentations were carried out for 5 days at $20{ }^{\circ} \mathrm{C}$ under constant agitation

2 (250 rpm), in duplicate. Data shown are the mean values of these measurements.

\subsubsection{Batch fermentation (Separate hydrolysis and fermentation)}

$150 \mathrm{~g}$ of defatted rapeseed meal was heat pretreated in a 2-litre glass bottle containing 1.35 litre of distilled water in an autoclave at $126{ }^{\circ} \mathrm{C}$ for $30 \mathrm{~min}$. After cooling down, $150 \mathrm{ml}$ of enzyme $(10 \% \mathrm{v} / \mathrm{v})$ were added to the vessel (giving a total of solids content $10 \% \mathrm{w} / \mathrm{v})$. Enzymatic hydrolysis was carried out in an orbital shaker (GFL 3015, SciQuip, UK) at $250 \mathrm{rpm}$ at $50{ }^{\circ} \mathrm{C}$ for $24 \mathrm{~h}$. Heat inactivation was applied at $95{ }^{\circ} \mathrm{C}$ for $10 \mathrm{~min}$ in a water bath (GD 120, Grant, Cambridge). The

9 produced hydrolysates were then filter-sterilised using $0.25 \mu \mathrm{m}$ Millipore stericup unit (EMD

10 Millipore Stericup ${ }^{\mathrm{TM}}$ ) and were aseptically transferred to a 2-litre bioreactor (BIOSTAT B,

11 Sartorious AG, German) with a working volume of 1.5 litres, previously autoclaved at $121^{\circ} \mathrm{C}$ for 20 min. Fermentation conditions were as follows; temperature, $20{ }^{\circ} \mathrm{C}$; agitation speed, $600 \mathrm{rpm}$;

13 aeration, 1 1/min. The $\mathrm{pH}$ of the hydrolysates was maintained at $\mathrm{pH} 6$ throughout the fermentation 14 by automatic additions of $\mathrm{NaOH}(2 \mathrm{M})$ via a peristaltic pump.

\subsubsection{Batch fermentation (Pre-hydrolysis and fermentation)}

In pre-hydrolysis and fermentation (pSSF) approach, enzymatic hydrolysis and subsequent fermentation of rapeseed meal were performed in one reactor. Two different enzymes were separately tested in this study (pectinase and Accellerase ${ }^{\circledR} 1500$ ). Firstly, $150 \mathrm{~g} / \mathrm{l}$ of rapeseed meal were added to the reactor with 1.35 litre of distilled water. The bioreactor was then subjected to autoclaving at $126^{\circ} \mathrm{C}$ for $30 \mathrm{~min}$. After cooling, $150 \mathrm{ml}$ of enzyme were added to the fermentation vessel (giving a total of solids content $10 \% \mathrm{w} / \mathrm{v}$ ) and the hydrolysis step was initiated at $50{ }^{\circ} \mathrm{C}$ for

$2224 \mathrm{~h}$. Agitation was controlled at $250 \mathrm{rpm}$ during this period. Once the hydrolysis step was completed, the vessel was cooled down to $20{ }^{\circ} \mathrm{C}$ followed by inoculation of $5 \%(\mathrm{v} / \mathrm{v})$ of $X$. dendrorhous pre-culture suspension. Fermentation conditions were as follows; temperature, $20{ }^{\circ} \mathrm{C}$; pH 6; agitation speed, 600 rpm; aeration, 1 1/min. 
Approximately $30 \mathrm{mg}$ freeze dried $X$. dendrorhous cells were prepared in $2 \mathrm{ml}$ Eppendorf

3 tubes. $0.3 \mathrm{~g}$ of glass bead (diameter $1 \mathrm{~mm}$ ) were added to the vials followed by addition of $1 \mathrm{ml}$

4 organic solvent. The yeast and beads suspension were mixed at $2000 \mathrm{rpm}$ for $10 \mathrm{~min}$ in a

5 ThermoMixer C (Eppendorf, Germany) to ensure similar rate of mixing for each sample. The

6 extraction temperature was controlled at $25{ }^{\circ} \mathrm{C}$. Subsequently, $0.1 \mathrm{ml}$ of $\mathrm{NaOH}(20 \% \mathrm{w} / \mathrm{v})$ was

7 added to the mixture, followed by further mixing for $5 \mathrm{~min}$ at $2000 \mathrm{rpm}$ in a ThermoMixer C. The

8 aqueous and organic phases were separated by centrifugation at $5423 \mathrm{x} \mathrm{g}$ for 5 min and organic

9 phase (top layer) was collected for astaxanthin measurement by spectrophotometer. The organic

10 solvents evaluated in this experiment were ethanol (EtOH, 99.8\%, MERCK), methanol $(\mathrm{MeOH}$,

11 100\%, Fisher Scientific), acetone (100\%, Merck), dimethyl sulfoxide (DMSO, 100\% Sigma-

12 Aldrich) and mixture of acetone: DMSO (1:1); distilled water was used as control/

\section{$13 \quad 2.7 \quad$ Solubility of Astaxanthin in Solvents}

The solubility of astaxanthin in organic solvents was tested. As such, ethanol (EtOH, 99.8\%,

15 MERCK), methanol (MeOH, 100\%, Fisher Scientific), acetone (100\%, Merck), dimethyl sulfoxide

16 (DMSO, 100\% Sigma-Aldrich), mixture of acetone:DMSO (1:1) as well as water were used as

17 solvents. Approximately $10 \mathrm{mg}$ of pure astaxanthin (Sigma Aldrich) were added to $1 \mathrm{ml}$ of solvent

18 in $2 \mathrm{ml}$ (Eppendorf) tubes and were then agitated at $1200 \mathrm{rpm}$ for $24 \mathrm{~h}$ at $25^{\circ} \mathrm{C}$ in a thermomixer

19 (Eppendorf). If a clear solution was observed, then additional amounts of astaxanthin $(\sim 2 \mathrm{mg})$ were

20 added to the mixture until there was a visual indication of undissolved material. The obtained

21 solvent/astaxanthin mixtures were diluted 100 times in methanol and filtered through a $0.2 \mu \mathrm{m}$

22 Polyvinyl Difluoride (PVDF) membrane filter. Finally, the concentration of astaxanthin in different

23 types of solvents was determined using HPLC analysis. 


\subsection{Analytical Methods}

The carbohydrate content of the rapeseed meal was modified based on analytical procedure

3 provided by National Renewable Energy Laboratory (NREL/TP-510-42618) [24]. Briefly, 300 mg

4 of rapeseed meal was pre-hydrolysed with $3 \mathrm{ml}$ of $72 \%(\mathrm{v} / \mathrm{v}) \mathrm{H}_{2} \mathrm{SO}_{4}$ at $30{ }^{\circ} \mathrm{C}$ for $1 \mathrm{~h}$. Subsequently,

$584 \mathrm{ml}$ of distilled water were added to the mixture in order to dilute the sulphuric acid content to 4

$6 \%(\mathrm{v} / \mathrm{v})$ and hydrolysis was carried out at $121{ }^{\circ} \mathrm{C}$ for $30 \mathrm{~min}$. The obtained mixtures were

7 neutralised with calcium carbonate to $\mathrm{pH}$ 5-6 and were analysed using a High Performance Anion

8 Exchange Chromatography with Pulsed Amperometric Detection (HPAEC-PAD) system (Dionex,

9 Thermo, UK). Samples were passed through a CarboPac PA1 column (4 x 250mm) at a flow rate of

$101 \mathrm{ml} / \mathrm{min}$ and the mobile phase consisted of $0.016 \mathrm{mM}$ of Sodium Hydroxide (NaOH) (eluent A)

11 and $0.5 \mathrm{mM}$ of Sodium Acetate $(\mathrm{NaOAc})$ (eluent $\mathrm{B}$ ) in a gradient method. Operating conditions

12 were as follows: Sample volume: $20 \mu \mathrm{l}$; mobile phase: $0.5 \mathrm{M} \mathrm{NaOH}, 0.1 \mathrm{M} \mathrm{NaOAc}$; column

13 temperature: $25^{\circ} \mathrm{C}$; flow rate: $1 \mathrm{ml} / \mathrm{min}$; gradient conditions: $\mathrm{T}_{0-40}, 100 \% \mathrm{~A}, \mathrm{~T}_{41-50}, 60 \% \mathrm{~A}, 40 \% \mathrm{~B}$,

$14 \mathrm{~T}_{51}, 100 \% \mathrm{~A}$.

The protein and fat content were measured by Kjeldahl and Soxhlet method, respectively (AOAC, 1990) and the lignin content was determined according to NREL protocol [24]. After hydrolysis with $72 \%$ (w/w) $\mathrm{H}_{2} \mathrm{SO}_{4}$ for $1 \mathrm{~h}$ at $30^{\circ} \mathrm{C}$, samples were hydrolysed with $1.0 \mathrm{M} \mathrm{H}_{2} \mathrm{SO}_{4}$ at $121{ }^{\circ} \mathrm{C}$ for $30 \mathrm{~min}$ in an autoclave. Samples were then filtered, and the filtrate was measured for

19 acid soluble lignin spectrophotometrically at $240 \mathrm{~nm}$. Acid Soluble Lignin (ASL) was calculated

20 according to equation $1(E q 1)$. The washed residue was dried at $100{ }^{\circ} \mathrm{C}$ for $18 \mathrm{~h}$. Subsequently, the

21 dried samples were placed in a furnace $\left(500{ }^{\circ} \mathrm{C} ; 5 \mathrm{~h}\right)$ and the residue was weighed and classified as

22 acid insoluble lignin. Total lignin was calculated as the sum of acid soluble and acid insoluble 23 lignin.

$$
\% A S L=\frac{A \times D F \times V(m l)}{\varepsilon \times P(g)} \times 100
$$


1 Where, $A$ is the absorbance at $240 \mathrm{~nm}, \mathrm{DF}$ is the dilution factor, $V$ is the volume of filtrate, $\varepsilon$ is the 2 coefficient at 30 and $P$ is the weight of biomass.

In the case of yeast fermentations, samples of $2 \mathrm{ml}$ were periodically withdrawn at regular time intervals. $1 \mathrm{ml}$ of sample was added into a pre-weight tube and centrifuged at $10845 \mathrm{x} g$ for 10 min. The supernatant was collected for sugar and ethanol analysis via HPLC. The pellet was washed twice with distilled water and frozen at $-20{ }^{\circ} \mathrm{C}$ prior to freeze drying (Virtis Sentry 2.0, UK). Biomass was measured by weight difference. In bioreactor experiments that involved prehydrolysis and fermentation steps, cell growth was monitored by total plate count method. Hence, $100 \mu \mathrm{l}$ of serially diluted samples were plated on Yeast and Mold agar plates (YM agar), incubated at $20^{\circ} \mathrm{C}$ for 5 days and biomass was expressed in $\mathrm{CFU} / \mathrm{ml}$. The sugar composition of the hydrolysates was determined by HPLC analysis (Agilent 1260 Infinity) with an Aminex HPX-87H column coupled to a differential refractometer and a diode array detector. Operating conditions were as follows: Sample volume: $20 \mu \mathrm{l}$; mobile phase: $5 \mathrm{mM} \mathrm{H}_{2} \mathrm{SO}_{4}$; flow rate: $0.6 \mathrm{ml} / \mathrm{min}$; column temperature: $65{ }^{\circ} \mathrm{C}$. Quantification of monosaccharides (glucose, galactose, xylose, arabinose), uronic acids and ethanol were achieved on the basis of standard curves, which were conducted using standard solutions.

Total carotenoid was quantified using Dimethyl Sulfoxide (DMSO) disruption method [26]. Briefly, $1 \mathrm{ml}$ of Dimethyl Sulfoxide (DMSO) was preheated at $55^{\circ} \mathrm{C}$ and added to the freeze dried biomass, followed by vortexing for $30-40 \mathrm{sec}$. Subsequently, $0.2 \mathrm{ml}$ of $20 \%$ sodium chloride $(\mathrm{NaCl})$ and $1.0 \mathrm{ml}$ of acetone were added to the mixture to extract the intracellular carotenoids. The aqueous and organic phases were separated after centrifugation at $5423 \times \mathrm{x}$ for $5 \mathrm{~min}$. The extraction process was repeated until a colourless biomass was obtained. The organic phases were then pooled together, and their absorbance was measured at $480 \mathrm{~nm}$ in a spectrophotometer. Values 
1 were then divided by the extinction coefficient of 2150 . The equation for total carotenoids

2 concentration is given in equation $2(E q 2)$ [26].

$$
\text { Carotenoid content }(\mu g / g)=\frac{A \times V(m l) \times 10^{4}}{A_{1 c m}^{1 \%} \times P(g)} \quad \text { Eq. } 2
$$

3 Where, $A$ is the absorbance at $480 \mathrm{~nm}, V$ is the volume, and $P$ is the weight of biomass and $A_{1 \mathrm{~cm}}^{1 \%}$ is 4 the coefficient of 2150 (based on determination using synthetic astaxanthin) [26].

\subsection{Scanning Electron Microscopy}

The morphology of the cell biomass samples prior and after extraction were analysed using

7 Quanta FEG 600 Environmental Scanning Electron Microscopy instrument (FEI Co. Inc.,

8 Hillsboro, Oregon). Samples were mounted onto SEM stubs using carbon tape and then sputter

9 coated with a thin layer of gold to prevent charging during imaging. The parameters used for 10 imaging were: $20 \mathrm{kV}$ of accelerating voltage, 4.0 spot size and a working distance approximately 10 $11-12 \mathrm{~mm}$. Images were recorded under vacuum at $6000 \mathrm{x}$ magnification.

\section{Results and Discussion}

\section{$13 \quad 3.1$ Compositional analysis of rapeseed meal}

During cold pressing, rapeseed undergoes a mild oil extraction process $\left(<40{ }^{\circ} \mathrm{C}\right)$ without the

15 use of solvents. Approximately 50-60\% of the initial oil is normally extracted from the seed and in 16 correspondence [27], the rapeseed meal used in this study contained substantial amounts of oil (16.7 $17 \pm 0.1 \%$ ). Table 2 shows the composition of rapeseed meal on a dry basis. The rapeseed meal was 18 rich in protein and carbohydrates, accounting for $26 \%$ and $35 \%(\mathrm{w} / \mathrm{w})$ of each, respectively. The 
1 protein content was lower than that reported in the literature [6] (i.e., $30 \%$, w/w), possibly due to

2 differences among rapeseed cultivars as well as due to differences in the oil extraction process [28].

The carbohydrate content was similar to that reported in the literature accounting for $36 \%$

$4(\mathrm{w} / \mathrm{w})[6]$. The monosaccharide composition indicated that the main polysaccharides present in the rapeseed meal were cellulose, hemicellulose and pectin. Glucose was the most abundant monosaccharide, i.e., equal to $20.2 \%(\mathrm{w} / \mathrm{w})$. The arabinose content was $\sim 6 \%(\mathrm{w} / \mathrm{w})$, the highest among the other sugars that are normally present in hemicellulose, namely galactose and xylose. It was reported that arabinose is the major hemicellulosic sugar present in rapeseed meal, suggesting

9 the presence of arabinans, which might be attached in the side chains of pectin [6]. Besides, the presence of xylose and arabinose probably originates from arabinoxylan structure in rapeseed meal.

11 Arabinoxylan is a hemicellulose consisting of a linear backbone of $\beta-1,4$ xylose residues with 12 arabinose substitution [29].

The presence of galactose $(2.9 \%, \mathrm{w} / \mathrm{w})$ could indicate the presence of galactomannan and arabinogalactan in the rapeseed meal. Moreover, the presence of galacturonic acid $(2.5 \%, \mathrm{w} / \mathrm{w})$ and 15 glucuronic acid $(0.6 \%, \mathrm{w} / \mathrm{w})$ further supported the presence of pectin in the rapeseed meal. Pectins have been reported as major polysaccharides in rapeseed meal apart from hemicellulose and cellulose $[6,30]$. Small amounts of fructose $(0.3 \% \mathrm{w} / \mathrm{w})$ were detected in the acid treated fraction of the rapeseed meal, in agreement with previously reported data in the literature $[4,30]$. In the water soluble fractions of rapeseed meal, small amounts of sucrose were also detected (data not

20 shown). Sucrose and fructose have been previously reported in the water soluble fractions of 21 rapeseed meal and normally act as an energy reserve in plants [4,6].

The analysis indicated the presence of $\sim 18 \%(\mathrm{w} / \mathrm{w})$ of total lignin, consisting of $1.9 \pm 0.1 \%$ (w/w) of acid soluble lignin and 16.1 $\pm 4.6 \%(\mathrm{w} / \mathrm{w})$ of Klason lignin. The amount of total lignin in rapeseed meal was similar to those $(\sim 16 \%)$ reported by studies investigating the production of biodiesel from rapeseed meal $[31,32]$. 
Rapeseed meal contained high amounts of carbohydrates and protein, however, most microorganisms cannot assimilate these compounds directly as they usually lack of cellulolytic and

4 proteolytic enzymes in their cluster [10]. Therefore, commercial enzymes were employed, targeting the conversion of cellulose and hemicellulose into monomeric sugars (glucose, galactose, xylose and arabinose). The generated hydrolysates were subsequently tested for their capability to support astaxanthin production by the yeast $X$. dendrorhous.

Figure 2 shows the effect of different enzyme concentrations on the release of monomeric

9 sugars after $24 \mathrm{~h}$ of hydrolysis using four different commercial enzymes (cellulase, pectinase,

10 Viscozyme ${ }^{\circledR}$ L and Accellerase ${ }^{\circledR}$ 1500). The sugar yield was defined as $g$ of sugars released after

$1124 \mathrm{~h}$ of hydrolysis per $\mathrm{g}$ of sugar originally present in the rapeseed meal. The highest glucose yield was observed by Viscozyme® L (53\%, w/w), followed by cellulase (47\%, w/w), pectinase $(41.8$ $\%, \mathrm{w} / \mathrm{w})$ and Accellerase ${ }^{\circledR} 1500(30 \%, \mathrm{w} / \mathrm{w})$. Viscozyme ${ }^{\circledR} \mathrm{L}$ is a multi-enzyme complex containing mixtures of cellulases, hemicellulases and xylanase and has also a proteolytic activity

$15[22,33,34]$. Hence, the synergistic effect of these enzymes rendered the rapeseed meal structure more accessible to enzymatic attack, resulting in the production of a hydrolysate rich in celluloseand hemicellulose-derived monomeric sugars. Galactose and arabinose were obtained at their highest yields when Viscozyme ${ }^{\circledR}$ L was used, equal to $74 \%(\mathrm{w} / \mathrm{w})$ and $79 \%(\mathrm{w} / \mathrm{w})$, respectively (Figure 2A).

According to the manufacturer's datasheet (Sigma Aldrich), cellulase contained mainly

21 endo- and exo- cellulases, thus their documented synergistic activities led to the effective hydrolysis of cellulose and $\beta$-glucans $[35,36]$. Endo-cellulases attack the $\beta$-1,4-glycosidic bonds randomly, targeting the amorphous region along the cellulose structure and produce either cellobiose or glucose. On the other hand, exo-cellulases act on the linkages from the non-reducing end of cellulose releasing cellobiose as the main reaction product [36]. Similar patterns were observed for 
1 the hemicellulose-derived monosaccharides in this study. Generally, increased enzyme

2 concentrations resulted in increased amounts of galactose, xylose and arabinose in the hydrolysate.

3 Xylose was detected in all hydrolysates except for those produced by cellulase (Figure 2C).

In terms of sugar concentrations in the hydrolysates, glucose and galactose were mainly present. In the case of Viscozyme ${ }^{\circledR}$ L hydrolysates (Figure $2 \mathrm{~A}$ ), the total sugar concentration when high enzyme loadings $(15 \%, \mathrm{v} / \mathrm{v})$ were used was $\sim 74 \mathrm{~g} / \mathrm{l}$, with glucose being $\sim 26 \mathrm{~g} / \mathrm{l}$ and fructose $~$ $17 \mathrm{~g} / \mathrm{l}$. It must be noted that approximately $\sim 16.5 \mathrm{~g} / \mathrm{l}$ of glucose and $\sim 17 \mathrm{~g} / \mathrm{l}$ of fructose were derived from the enzymatic hydrolysis of sucrose that was present in the Viscozyme ${ }^{\circledR}$ L formulation and is generally used as a preservative in enzyme formulations. In the case of pectinase (Figure $2 \mathrm{~B}$ ), the total concentration of monomeric sugars in the hydrolysates accounted for approximately $20 \mathrm{~g} / \mathrm{l}$, with glucose and galactose being the principle sugars. However, $66 \mathrm{~g} / \mathrm{l}$ of glycerol was also detected in the hydrolysates that originated from the enzyme formulation itself, which could potentially act as an additional carbon source for microbial fermentation. As for cellulase (Figure 2C), the total sugar concentration was $\sim 76 \mathrm{~g} / \mathrm{l}$, the majority of which was glucose $(71 \mathrm{~g} / \mathrm{l})$, although $\sim 64 \mathrm{~g} / \mathrm{l}$ of glucose were attributed to the enzyme formulation. In Accellerase ${ }^{\circledR} 1500$ treated hydrolysates, 11 $\mathrm{g} / \mathrm{l}$ of total sugars were present, with glucose $(\sim 6 \mathrm{~g} / \mathrm{l})$ and galactose $(\sim 4 \mathrm{~g} / \mathrm{l})$ being the most prominent sugars. The synergistic action of enzyme mixtures assists in further break down of carbohydrate polymers, as indicated by the action of pectinase on rapeseed meal. This was demonstrated by a greater hydrolysis yield of rapeseed meal, as $41 \%(\mathrm{w} / \mathrm{w})$ of glucose was extracted using pectinase enzyme, which contained a mixture of side activities including cellulase and hemicellulase. In contrast, Accellerase ${ }^{\circledR} 1500$ treatment that did not exert pectinase activity, resulted in lower glucose yields $(30 \%, \mathrm{w} / \mathrm{w})$. The enzymatic hydrolysis of rapeseed meal has been widely reported on the rapeseed protein extraction rather than on carbohydrates. Three different enzymes (Celluclast, Viscozyme ${ }^{\circledR}$ L and Pectinase G) were tested, both singularly and in combination, in order to hydrolyse dilute acid pretreated rapeseed meal that was subsequently used for succinic acid production by Actinobacillus succinogenes [11]. Around $28.6 \mathrm{~g} / \mathrm{l}$ of total sugars 
1 were released from rapeseed meal after Pectinase G (2\%,w/w) hydrolysis that consisted of sucrose,

2 glucose, fructose and arabinose [11]. In another study, Viscozyme® L was found to assist in protein

3 hydrolysis from rapeseed meal with high protein yield (68\%) and total carbohydrates yield (80\%

4 of total reducing sugars) [22].

Due to the absence of additional preservatives in the formulation, the Accellerase ${ }^{\circledR} 1500$ enzyme was chosen for further investigation, as the composition of its hydrolysate is a direct reflection of rapeseed meal derived sugars. As such, a thermal pre-treatment step was carried out to evaluate its effectiveness towards enhancing the enzymatic hydrolysis of rapeseed meal. Table 3

9 presents the composition of rapeseed meal hydrolysates following heat pre-treatment and enzymatic 10 digestion by Accellerase $1500(10 \% \mathrm{v} / \mathrm{v})$. Heat pre-treatment at $126{ }^{\circ} \mathrm{C}$ for $30 \mathrm{~min}$ was found to 11 significantly increase $(\mathrm{p}<0.05)$ glucose hydrolysis yield by $17 \%$ compared to control (no pre12 treatment). However, higher temperature conditions $\left(135^{\circ} \mathrm{C}\right.$ for $\left.30 \mathrm{~min}\right)$ resulted in lower sugar 13 yields compared to those at $126^{\circ} \mathrm{C}$. This was most likely due to the more prominent degradation of 14 glucose to furfural and 5-hydroxymethyl-2-furaldehyde (HMF) under higher temperature in the 15 presence of mild acid conditions. The acidic environment is generated due to the partial acetylation 16 of hemicellulose, leading to the hydrolysis of acetyl ester bonds into acetic acid during the heat pre17 treatment process [54]. Similar to glucose, the recovery of the hemicellulosic-derived sugars also 18 decreased when higher pre-treatment temperatures were applied.

\subsection{Microbial Production of Astaxanthin in Rapeseed Meal Hydrolysates}

\subsubsection{Batch Shake flask fermentations}

A key objective of this study was to investigate the suitability of rapeseed meal hydrolysates as fermentation media for the microbial production of astaxanthin. Therefore, rapeseed meal 
1 hydrolysates produced by the action of the four commercial enzymes were initially tested in flask

2 cultures for their capability to support $X$. dendrorhous growth and astaxanthin production.

As shown in Table 4, significantly different cell biomass and astaxanthin production values were obtained depending upon the hydrolysate. In terms of total biomass and astaxanthin production, the best substrate was the pectinase hydrolysate $(\sim 26 \mathrm{~g} / \mathrm{l}$ of cell biomass, $6.7 \mathrm{mg} / \mathrm{l} \mathrm{of}$ astaxanthin), whereas Viscozyme ${ }^{\circledR}$ hydrolysate had the poorest performance $(\sim 3 \mathrm{~g} / \mathrm{l}$ of cell biomass, $0.4 \mathrm{mg} / \mathrm{l}$ of astaxanthin). However, in terms of biomass yield on substrate consumption $\left(\mathrm{Y}_{\mathrm{X} / \mathrm{S}}\right)$ and astaxanthin yield on cell biomass $\left(\mathrm{Y}_{\mathrm{P} / \mathrm{X}}\right)$, the highest values $(0.84 \mathrm{~g} / \mathrm{g}$ and $332 \mu \mathrm{g} / \mathrm{g}$, respectively) were obtained when Accellerase ${ }^{\circledR} 1500$ hydrolysate was used. In the pectinase hydrolysate, the YP/X value was $258 \mu \mathrm{g} / \mathrm{g}$, whereas, lower values were obtained for the Viscozyme ${ }^{\circledR}$

11 hydrolysate $(156 \mu \mathrm{g} / \mathrm{g})$ and the Cellulase hydrolysate $(71 \mu \mathrm{g} / \mathrm{g})$. The low astaxanthin concentrations 12 obtained in the Viscozyme ${ }^{\circledR}$ and cellulase hydrolysates were most likely associated with the 13 relatively high hexose concentrations (> $50 \mathrm{~g} / \mathrm{l}$ ). Such high sugar concentrations can initiate 14 Crabtree effect in $X$. dendrorhous which changes the yeast metabolism from respiration to alcoholic 15 fermentation, leading to ethanol production, which inhibits cell growth and astaxanthin 16 accumulation in the cells [37-39]. Indeed, in the case of the cellulase hydrolysate, the highest 17 amount of ethanol was produced $(6.9 \mathrm{~g} / \mathrm{l})$ and the second highest in the case of Viscozyme ${ }^{\circledR}(3.8$ $18 \mathrm{~g} / \mathrm{l})$. In the former, the high initial glucose concentration the hydrolysate $(45 \mathrm{~g} / \mathrm{l})$ benefited cell 19 biomass production (14 g/l) but compromised the production of astaxanthin during secondary metabolism $(1.1 \mathrm{mg} / \mathrm{l})$; correspondingly, a similar trend was observed in the latter.

However, in the case of the pectinase hydrolysate, no ethanol was detected, a fact which indirectly suggested that the Crabtree effect was suppressed as glycerol was the predominant carbon source in the medium rather than hexose sugars. As for Accellerase ${ }^{\circledR} 1500$ hydrolysis, two types of rapeseed meal samples were used (crude samples and thermal pretreated samples). Between these two samples, different fermentation results were obtained where pretreated samples resulted in 
1 higher biomass $(12 \mathrm{~g} / \mathrm{l})$ and astaxanthin production $(3.2 \mathrm{mg} / \mathrm{l})$. It is interesting to note that ethanol

2 was detected in this fermentation only in trace amounts $(<1 \mathrm{~g} / \mathrm{l})$.

The involvement of two possible mechanisms in the induction of pigmentation by ethanol has been proposed before [40]. The first proposed mechanism involves the enzyme aldehyde oxidase that generates superoxide radicals, which are responsible for the induction of carotenoid synthesis. The second mechanism is the conversion of ethanol by alcohol dehydrogenase to acetate; in the presence of energy (ATP), acetate can then be converted to acetyl CoA, which is the major precursor for both the Tricarboxylic Acid (TCA) cycle and the mevalonate pathway, the latter being responsible for carotenoid production [40,41]. In addition, ethanol might induce the production of pigments by inducing the expression of phytoene $\beta$-carotene synthase (crtYB) and astaxanthin synthase (crtS) genes, which are responsible for the production of carotenoids in mevalonate pathway [40]. The observed decrease in the ethanol concentration indicated the presence of alcohol dehydrogenase in this particular $X$. dendrorhous strain and the generated acetyl-CoA was used for astaxanthin synthesis (hence the increase in astaxanthin concentration during the stationary phase) rather than for the production of biomass through the TCA cycle.

Figure Error! Reference source not found. 3 depicts the kinetic profile of $X$. dendrorhous cultivated in the pectinase hydrolysate in batch flasks fermentations. The pectinase hydrolysate consisted of $\sim 15.7 \mathrm{~g} / \mathrm{l}$ of sugars (glucose, galactose, xylose and arabinose) as well as $40 \mathrm{~g} / \mathrm{l}$ of glycerol, which was originally present in the enzyme formulation. All sugars were utilised by the cells, with glucose being the most preferred one (hence utilised first), followed by hemicellulose derived sugars. Once all sugars were exhausted from the hydrolysate, glycerol was utilised as an energy and carbon source for biomass production and astaxanthin accumulation. In contrast to the Accellerase ${ }^{\circledR} 1500$ hydrolysate, the cells did not experience a lag phase in the pectinase hydrolysate. The cells continued to grow throughout the fermentation period $(1 \mathrm{~h}-120 \mathrm{~h})$ and showed a growth pattern similar to diauxic growth, reflecting the sequential consumption of sugars and glycerol (Fig. 3B). The cell biomass achieved in the case of the pectinase hydrolysate was the 
1 highest amongst all hydrolysates ( $26 \mathrm{~g} / \mathrm{l})$. This was due to the relatively low sugar concentration

2 and the fact the glycerol, which was present in substantial amounts does not initiate a Crabtree

3 effect. Astaxanthin was produced throughout the fermentation (including during the glycerol

4 consumption phase) reaching $6.7 \mathrm{mg} / \mathrm{l}$, significantly higher than in the case of the two Accellerase ${ }^{\circledR}$

51500 hydrolysates (2.7 and $3.2 \mathrm{mg} / \mathrm{l})$ although the astaxanthin yield was slightly lower (Table 4).

6 The reason for this could be the fact that in the case of the Accellerase ${ }^{\circledR} 1500$ hydrolysates, small

7 amounts of ethanol were produced which (as discussed above) can potentially stimulate astaxanthin

8 production, whereas in the pectinase hydrolysate fermentation ethanol was not detected. Another

9 reason for the lower astaxanthin yield could be the absence of certain minerals in the pectinase

10 hydrolysate, which are important for carotenoid production [42]. More specifically, several metals

11 including zinc, iron, copper and magnesium have been reported to act as carotenoid inducers in

12 certain yeast species such as Rhodotorula glutinis and Rhodotorula graminis [43]. Moreover, high

13 levels of antinutritional components such as glucosinolates and phenols, which are present in 14 rapeseed meal might also inhibit carotenoid synthesis [44].

To our knowledge, no studies are currently available in the literature investigating the use of rapeseed meal for the growth of $X$. dendrorhous. However, previous studies have reported that $X$. dendrorhous was able to grow well on enzymatic hydrolysates of wood supplemented with glucose 18 and produce under optimised conditions approximately $1.8 \mathrm{mg}$ of total carotenoids/l [45]. In this 19 study, the rapeseed meal hydrolysates were able to support higher astaxanthin production and high astaxanthin yields, indicating that this medium contained sufficient nutrients for optimal cell

21 growth. In a different study, 5\% molasses supplemented with urea (30 g/l) and sodium phosphate (4.5 g/l) were used to cultivate $X$. dendrorhous GM807 in shake flasks. The use of molasses demonstrated positive effects of yeast growth $(3.5 \mathrm{~g} / \mathrm{l})$, but not on the astaxanthin formation (105

$24 \mu \mathrm{g} / \mathrm{g}$ ) [46]. Besides that, a mutant strain of Xanthophyllomyces dendrorhous was cultivated in a Yucca plant-based medium supplemented with date juice in fed-batch fermentation system and resulted to very high cell biomass $(39 \mathrm{~g} / \mathrm{l})$, astaxanthin production $(24 \mathrm{mg} / \mathrm{l})$ and astaxanthin yield 
$1 \quad(600 \mu \mathrm{g} / \mathrm{g})$ [47]. This indicates the potential to genetically engineer $X$. dendrorhous strains in order

2 to achieve high conversion yields, which will render the potential commercialisation of the

3 microbial production of astaxanthin from low value agri-food materials such as rapeseed meal more

4 economically viable.

\subsubsection{Batch fermentations (Separate hydrolysis and fermentation)}

Fermentations were carried out in a 2-1 stirred tank bioreactor to investigate the yeast growth and astaxanthin production under controlled conditions. In addition, separate saccharification and fermentation (SHF) strategy was implemented, whereby rapeseed meal hydrolysis was performed in

9 a separate vessel and prior to $X$. dendrorhous fermentation. Two types of rapeseed meal hydrolysates treated by different enzymes (Accellerase ${ }^{\circledR} 1500$ and pectinase) were used.

Figure 4 shows the growth profile of $X$. dendrorhous in two different rapeseed meal hydrolysates and Table 5 presents the main fermentation data of these trials. The composition of rapeseed meal hydrolysates derived from Accellerase ${ }^{\circledR} 1500$ consisted of $13 \mathrm{~g} / \mathrm{l}$ of total sugars (glucose, xylose and galactose). The utilisation of this hydrolysate as fermentation medium resulted in $14.3 \mathrm{~g} / \mathrm{l}$ of biomass and $3.6 \mathrm{mg} / \mathrm{l}$ of astaxanthin $(P)$. By observing the substrate consumption

16 profile, it can be noted that glucose was used as a primary carbon source, and upon its depletion, hemicellulosic derived sugars were then consumed. The astaxanthin yield on cell biomass (Y $\mathrm{P} / \mathrm{X})$, was equal to $250 \mu \mathrm{g} / \mathrm{g}$ of produced biomass. These values were higher compared to those obtained

19 in shake flask fermentations utilising rapeseed meal hydrolysates as substrate $(12 \mathrm{~g} / \mathrm{l}$ of biomass and $203.2 \mathrm{~g} / \mathrm{l}$ of astaxanthin). It is evident that the optimised process conditions led to higher biomass and 21 astaxanthin production, due to the provision of better dispersion of nutrients and adequate oxygen supply in the bioreactor, in which had a positive impact on cell growth and astaxanthin production.

Batch bioreactor fermentations using pectinase derived hydrolysates were also carried out, with the hydrolysates consisting of $20 \mathrm{~g} / \mathrm{l}$ of total monomeric sugars and glycerol $(52 \mathrm{~g} / \mathrm{l})$ that was sourced from the enzyme formulation as previously mentioned. $X$. dendrorhous cultivation in this 
1 hydrolysate was most preferable for biomass (42 g/l). The concentration of astaxanthin, $P(10.2$

$2 \mathrm{mg} / \mathrm{l})$ was positively correlated with high biomass production. These data clearly showed that

3 glycerol acted as additional carbon source for biomass production; upon exhaustion of the main

4 sugars in the media, glycerol started to be consumed as demonstrated by the diauxic growth curve 5 on this occasion (indicated by an arrow in Figure 5B).

Total biomass production was positively correlated with increased sugars concentration in all tested hydrolysates. However, in terms of biomass yield (Yx/s), it was found out that Accellerase ${ }^{\circledR}$ treated hydrolysates best supported biomass production (Table 5). Furthermore, the biomass yield was higher under controlled environment (bioreactor) as compared to shake flasks fermentation using similar hydrolysates. In terms of astaxanthin yield on biomass ( $\mathrm{Y}_{\mathrm{P} / \mathrm{X}}$ ), the values for both

11 hydrolysates were similar $(\sim 250 \mu \mathrm{g} / \mathrm{g})$, indicating that the type of carbon source did not affect the 12 accumulation of astaxanthin. In comparison with semi-defined media with $30 \mathrm{~g} / \mathrm{l}$ of glucose as 13 initial carbon source, it was expected that biomass production was higher $(16 \mathrm{~g} / \mathrm{l})$ compared to 14 Accellerase ${ }^{\circledR} 1500$ treated hydrolysates $(14 \mathrm{~g} / \mathrm{l})$ that contained less carbon source available $(13 \mathrm{~g} / \mathrm{l})$, however, astaxanthin production $(P)$ were similar $(3.6 \mathrm{mg} / \mathrm{l})$ in both fermentations. This suggests the ability of the particular yeast to produce higher intracellular astaxanthin in Accellerase® 1500 hydrolysates $\left(\mathrm{Y}_{\mathrm{p} / \mathrm{x}}=251 \mu \mathrm{g} \mathrm{g}\right)$ as compared to semi-defined media $\left(\mathrm{Y}_{\mathrm{p} / \mathrm{x}}=221 \mu \mathrm{g} / \mathrm{g}\right)$. The complex composition of the rapeseed meal hydrolysates, composed of mixtures of sugars, protein and other nutrients, seems to promote astaxanthin production in X. dendrorhous.

\subsubsection{Batch fermentation (Pre-hydrolysis and fermentation)}

The possibility of conducting pre-hydrolysis and fermentation (pSSF) strategy was investigated, with a view to improve yeast growth as well as astaxanthin production in $X$. dendrorhous. pSSF strategy is an improvement of simultaneous saccharification and fermentation (SSF) strategy that has been widely used in bioethanol production by Saccharomyces cerevisiae [35]. In SSF strategy, enzymatic hydrolysis of cellulosic material and microbial fermentation is 
1 performed simultaneously. However, problems often arise mainly due to the difference in the

2 optimal temperatures of the enzymatic hydrolysis and yeast fermentation. In our case, the

3 significant difference between optimal temperature for enzymatic hydrolysis of rapeseed meal and

$4 X$. dendrorhous growth rendered the SSF approach not feasible. To this end, the vessel temperature

5 was set at $50{ }^{\circ} \mathrm{C}$ for $24 \mathrm{~h}$ (the optimal temperature for enzyme hydrolysis), followed by reducing the

6 temperature to $20^{\circ} \mathrm{C}$ (optimal temperature for $X$. dendrorhous), prior to inoculation.

Figure 55 depicts the growth profile of $X$. dendrorhous cultivated in a 2-litre bioreactor using 8 pSSF approach in Accellerase ${ }^{\circledR} 1500$ hydrolysates (A) and pectinase hydrolysates (B). In the case 9 of pSSF using Accellerase ${ }^{\circledR} 1500$ hydrolysates, total astaxanthin production was $30 \%$ lower than 10 in SHF cultivation process utilising the same hydrolysates. This might occur due to the presence of 11 rapeseed biomass in the bioreactor, in which led into collisions between rapeseed meal biomass and 12 yeast cells during agitation and eventually cell disruption.

In the case of pectinase derived rapeseed meal hydrolysates, it was observed that the sugars 14 released during hydrolysis step were used as primary carbon sources. Generally, about $70 \mathrm{~g} / \mathrm{l}$ of 15 total carbon sources ( $22 \mathrm{~g} / \mathrm{l}$ sugars and $\sim 48 \mathrm{~g} / \mathrm{l}$ glycerol) were available for yeast consumption. It was observed that glycerol started to be consumed once available sugars were exhausted in the media, demonstrating that cells were able to divert their metabolism towards glycerol consumption.

18 It is interesting to observe that during the period of glycerol metabolism, glucose was also released 19 in the hydrolysates by the slow activity of pectinase on rapeseed meal at $20^{\circ} \mathrm{C}$ (as opposed to 20 optimum temperature of pectinase activity at $50^{\circ} \mathrm{C}$ ). At the end of the fermentation, glycerol was 21 completely consumed by the yeast and about $3.5 \mathrm{~g} / \mathrm{l}$ of excess glucose remained in the media. In the pSSF approach with pectinase derived rapeseed meal hydrolysates similar results for astaxanthin 23 production were noted as in batch fermentation with separate hydrolysis and fermentation experiment ( 10 mg/l). 
Figure 6 presents the results from the astaxanthin extraction with glass beads aiming to disrupt the yeast cell, coupled with different types of solvent to extract astaxanthin simultaneously.

4 The highest extraction was achieved with acetone (95\%,w/w), followed by DMSO: Acetone (84 $\%, \mathrm{w} / \mathrm{w})$. Methanol and ethanol were not significantly different from each other $(54-58 \%$, w/w), whereas DMSO on its own resulted in low extraction yield (42\%, w/w) and water in the lowest (14 $\%$, w/w). This might have occurred due to the fact that acetone has good permeability through the cell wall and membrane of $X$. dendrorhous as well as high solubility to astaxanthin [48]. The difference in the extraction yield obtained with the different solvents could be attributes to the differences in their polarity which were: Ethanol (4.3) < methanol (5.1) < acetone $(5.4)<$ DMSO (7.2) < water (9.00) [48]. As astaxanthin contains both polar (at the end of the molecule) and nonpolar moieties (in the middle of the molecule) in its chemical structure [49], the use of slightly polar solvent helps to extract astaxanthin from the cell wall membrane of the yeast that might be attached by the non-covalent binding to specific protein [50].

In order to understand better the mechanisms of astaxanthin extractability, the solubility of astaxanthin in different solvents were tested (Table 6). The highest solubility of pure astaxanthin was observed with a combination of DMSO and acetone (1:1), whereas a lower astaxanthin solubility was found in DMSO and acetone alone. The solubility of astaxanthin is highly correlated with polarity of the solvent used. The highest astaxanthin solubility was observed a when mixture of DMSO: Acetone (1:1) was used with $2.03 \mathrm{mg} / \mathrm{ml}$. As for astaxanthin solubility in individual solvent, highest solubility of astaxanthin was observed when DMSO was used, that correlated to the high polarity of DMSO. Even though astaxanthin has low solubility in acetone $(0.55 \mathrm{mg} / \mathrm{ml})$ as compared to DMSO, it has high permeability through the yeast cell wall and resulted in higher astaxanthin extractability from the yeast cells [48]. The mechanism of astaxanthin extraction with organic solvents occur by permeation of solvents through the cell wall and cell membrane, and subsequently interact with astaxanthin compound using Van der Waals forces. This 
1 solvent/astaxanthin complex will diffuse across the cell membrane and remain dissolve in solvents [51].

Several studies report the utilisation of glass beads to extract intracellular products from various yeast species using beads extraction on wider aspects but are limited with regards to astaxanthin extraction form $X$. dendrorhous. Glass beads extraction was achieved by disrupting the yeast cells via bead collision zones by compaction or shear force with energy transfer from beads to the cells [52]. Glass beads accompanied with acetone were used to rupture Sporodiobolus pararoseus and Rhodotorula mucilaginosa. Results showed that about $66 \%$ (w/w) and $52 \%(\mathrm{w} / \mathrm{w}$ ) of carotenoids extractability was obtained as compared to standard DMSO method [53]. In different study, two different methods (glass beads in bead beater and DMSO/solvent) of astaxanthin extraction in four different strains of Phaffia rhodozyma cells was investigated [26]. Similar results were obtained between these methods $(275-276 \mu \mathrm{g} / \mathrm{g})$. However, the DMSO disruption method is more rapid than glass bead disruption process, in which multiple samples can be processed at the same time, the DMSO method is considered more suitable for large number of samples. However, the drawbacks of this process are that it is a non-selective extraction process where all polar/nonpolar compounds were extracted depending on the solvents used during the process.

The resultant morphology of the $X$. dendrorhous cells after glass beads treatment was studied by environmental scanning microscopy (Figure 7). Before the glass beads treatment, cells were in intact sphere shapes with a smooth surface. After treatment, small particles $(<5 \mathrm{~mm})$ were produced as a result of beads abrasion (Figure 7B), as compared with intact cells before disruption

21 (Figure 7A). The small sized cells and debris produced after glass beads treatment resulted in an increased surface area for subsequent solvent extraction, leading to higher astaxanthin extractability. Apparently, at this point, astaxanthin extraction was highly dependent on the solubility and polarity of organic solvents used, as the degree of cell disruption was already high.

25 For example, in glass beads accompanied with water extraction, minimum astaxanthin pigments were extracted even though the cells were ruptured. This is attributed to the ability of the solvent 
1 used to penetrate the debris/cells to extract the pigments as well as astaxanthin was not soluble in

2 water. It can be deduced that the types of organic solvents used in astaxanthin extraction are very

3 crucial for the success rate of the process.

Yeast derived astaxanthin is characterised as natural and can be used as an ingredient in products formulation including feed, food and as a colourant. The experiments demonstrated that

6 the application of mechanical extraction (glass beads) gave high degree of cell disruption and

7 subsequently increased astaxanthin extraction by solvent. This is considered as a feasible method to

8 be used in large scale as it is simple, cheap and reliable and does not require special

9 instrumentation. Moreover, further studies on the astaxanthin extract are required to investigate the

10 stability of the extract in different types of solvents. Investigating the performance of the extracted

11 astaxanthin in product formulation such as in feed and colourant, is a key future step for the

12 biotechnological production of astaxantin.

\section{Conclusion}

One of the challenges in natural astaxanthin production is associated with its expensive

16 production route compared to synthetically produced astaxanthin, as it involves a series of processes

17 including fermentation and downstream processing. Improvement of the process should target high

18 astaxanthin yields in order to render the overall process more valuable and allow for microbial

19 astaxanthin to compete with synthetically produced astaxanthin. Rapeseed meal holds potential as

20 substrate for the microbial production of astaxanthin. This work demonstrated a process for

21 rapeseed meal bioconversion into astaxanthin by $X$. dendrorhous DSMZ 5626. The process flow

22 starts from screening commercial enzymes for their potential as biocatalysts for rapeseed meal

23 conversion into carbon source rich hydrolysate, down to fermentation optimisation and extraction

24 process. This approach could offer a sustainable alternative to chemically synthesised astaxanthin

25 and can stimulate the circular bioeconomy through the utilisation of low value, abundant resources. 
Financial support has been provided by the Ministry of Higher Education Malaysia under Academic

4 Training Scheme Sponsorship.

\section{References}

[1] Krautgartner R, Audran X, Erik Rehder L, Boshnakova M, Dobrescu M, Rossetti A. Oilseeds market Update. USDA Foreign Agric. Serv. 2017;

[2] Department for Environment, Food and Rural Affairs Department of Agriculture, Environment and Rural Affairs (Northern Ireland) Welsh Assembly, The Department for

[5] Jeong H-S, Kim H-Y, Ahn SH, Oh SC, Yang I, Choi I-G. Effects of combination processes on the extraction of pectins from rapeseed cake (Brassica napus L.). Food Chem. 2013;139:9-15.

[6] Pustjens AM, Schols HA, Kabel MA, Gruppen H. Characterisation of cell wall

[7] Uçkun Kiran E, Salakkam A, Trzcinski AP, Bakir U, Webb C. Enhancing the value of nitrogen from rapeseed meal for microbial oil production. Enzyme Microb. Technol. 2012;50:337-42.

[8] El-Beltagi HES, Mohamed AA. Variations in fatty acid composition, glucosinolate profile and some phytochemical contents in selected oil seed rape (Brassica napus L.) cultivars. Grasas y Aceites 2010;61:143-50.

[9] Jeong H-SS, Kim H-YY, Ahn SH, Oh SC, Yang I, Choi I-GG. Optimization of enzymatic hydrolysis conditions for extraction of pectin from rapeseed cake (Brassica napus L.) using commercial enzymes. Food Chem. 2014;157:332-8.

[10] Chatzifragkou A, Papanikolaou S, Kopsahelis N, Kachrimanidou V, Dorado MP, Koutinas A. Biorefinery development through utilization of biodiesel industry by-products as sole fermentation feedstock for 1,3-propanediol production. Bioresour. Technol. 2014;159:16775. 
[11] Chen K, Zhang H, Miao Y, Wei P, Chen J. Simultaneous saccharification and fermentation of acid-pretreated rapeseed meal for succinic acid production using Actinobacillus succinogenes. Enzyme Microb. Technol. 2011;48:339-44.

[12] García IL, López JA, Dorado MP, Kopsahelis N, Alexandri M, Papanikolaou S, et al. Evaluation of by-products from the biodiesel industry as fermentation feedstock for poly(3hydroxybutyrate-co-3-hydroxyvalerate) production by Cupriavidus necator. Bioresour. Technol. 2013;130:16-22.

[13] Ambati RR, Moi PS, Ravi S, Aswathanarayana RG. Astaxanthin: Sources, extraction, stability, biological activities and its commercial applications - A review. Mar. Drugs 2014;12:128-52.

[14] Lobo V, Patil A, Phatak A, Chandra N. Free radicals, antioxidants and functional foods: Impact on human health. Pharmacogn. Rev. 2010;4:118-26.

[15] Fassett RG, Coombes JS. Astaxanthin: A potential therapeutic agent in cardiovascular disease. Mar. Drugs 2011;9:447-65.

[16] Ip P-F, Wong K-H, Chen F. Enhanced production of astaxanthin by the green microalga Chlorella zofingiensis in mixotrophic culture. Process Biochem. 2004;39:1761-6.

[17] Baker R, Günther C. The role of carotenoids in consumer choice and the likely benefits from their inclusion into products for human consumption. Trends Food Sci. Technol. 2004;15:484-8.

[18] Panel EF. Scientific Opinion on the Safety and Efficacy of Synthetic Astaxanthin as Feed Additive for Salmon and Trout, Other Fish, Ornamental Fish, Crustaceans and Ornamental Birds. EFSA J. 2014;12:3724.

[19] Bhatt PC, Ahmad M, Panda BP. Enhanced bioaccumulation of astaxanthin in Phaffia rhodozyma by utilising low - cost agro products as fermentation substrate. 2012;

[20] Panis G, Carreon JR. Commercial astaxanthin production derived by green alga Haematococcus pluvialis: A microalgae process model and a techno-economic assessment all through production line. Algal Res. 2016;18:175-90.

[21] Guerin M, Huntley ME, Olaizola M. Haematococcus astaxanthin: applications for human health and nutrition [Internet]. Trends Biotechnol.2003 [cited 2017 Apr 5];21:210-6. Available from: http://linkinghub.elsevier.com/retrieve/pii/S0167779903000787

[22] Rodrigues IM, Carvalho MGVS, Rocha JMS. Increasing the protein content of rapeseed meal by enzymatic hydrolysis of carbohydrates. BioResources 2014;9:2010-25.

[23] Sari YW, Bruins ME, Sanders JPM. Enzyme assisted protein extraction from rapeseed, soybean, and microalgae meals. Ind. Crops Prod. 2013;43:78-83.

[24] Sluiter A, Hames B, Ruiz RO, Scarlata C, Sluiter J, Templeton D, et al. Determination of Structural Carbohydrates and Lignin in Biomass. Laboratory ANalytical Procedure (LAP). 2004.

[25] AOAC. AOAC: Official Methods of Analysis (Volume 1). Off. Method Anal. AOAC $1990 ; 15$. 
[26] Sedmak JJ, Weerasinghe DK, Jolly SO. Extraction and Quantification of Astaxanthin from Phaffia Rhodozyma. Biotechnol. Tech. 1990;4:107-12.

[27] Mintec. Rapeseed oil : commodity factsheet. 2012.

[28] Leming R, Lember A. Chemical Composition of Expeller-Extracted and Cold-Pressed Rapeseed Cake. 2002;103-9.

[29] Butardo VM, Sreenivasulu N. Tailoring Grain Storage Reserves for a Healthier Rice Diet and its Comparative Status with Other Cereals. Int. Rev. Cell Mol. Biol. 2016;323:31-70.

[30] Bell JM. Nutrients and toxicants in rapeseed meal: a review. J. Anim. Sci. 1984;58:9961010.

[31] Briones R, Serrano L, Labidi J. Valorization of some lignocellulosic agro-industrial residues to obtain biopolyols. J. Chem. Technol. Biotechnol. 2012;87:244-9.

[32] Egües I, Alriols MG, Herseczki Z, Marton G, Labidi J. Hemicelluloses obtaining from rapeseed cake residue generated in the biodiesel production process. J. Ind. Eng. Chem. 2010;16:293-8.

[33] Guan X, Yao H. Optimization of Viscozyme L-assisted extraction of oat bran protein using response surface methodology. Food Chem. 2008;106:345-51.

[34] Hanmoungjai P, Pyle DL, Niranjan K. Enzyme-assisted water-extraction of oil and protein from rice bran. J. Chem. Technol. Biotechnol. 2002;77:771-6.

[35] Taherzadeh MJ, Karimi K. Enzyme-based hydrolysis processes for ethanol from lignocellulosic materials: A review. 2007.

[36] Yoo CG. Pretreatment and fractionation of lignocellulosic biomass for production of biofuel and value-added products. 2012;

[37] Liu Y. Investigation of Major Biochemical Factors for Improved Carotenoid (Astaxanthin) Production by the Yeast Xanthophyllomyces dendrorhous. 2006;

[38] Marova I, Certik M, Breierova E. Production of Enriched Biomass by Carotenogenic Yeasts Application of Whole-Cell Yeast Biomass to Production of Pigments and Other Lipid Compounds. Biomass - Detect. Prod. Usage 2011;345-84.

[39] Yamane YI, Higashida K, Nakashimada Y, Kakizono T, Nishio N. Influence of oxygen and glucose on primary metabolism and astaxanthin production by Phaffia rhodozyma in batch and fed-batch cultures: Kinetic and stoichiometric analysis. Appl. Environ. Microbiol. 1997;63:4471-8.

[40] Marcoleta A, Niklitschek M, Wozniak A, Lozano C, Alcaíno J, Baeza M, et al. "Glucose and ethanol-dependent transcriptional regulation of the astaxanthin biosynthesis pathway in Xanthophyllomyces dendrorhous.” BMC Microbiol. 2011;11:190.

[41] Thomson JM, Gaucher EA, Burgan MF, De Kee DW, Li T, Aris JP, et al. Resurrecting ancestral alcohol dehydrogenases from yeast. Nat. Genet. 2005;37:630-5.

[42] Sanpietro LMD. Studies of Astaxanthin Biosynthesis in Xanthophyllomyces dendrorhous (Phaffia rhodozyma). Effect of Inhibitors and Low Temperature. Yeast 1998;14:1007-16. 
[43] Mata-Gómez LC, Montañez JC, Méndez-Zavala A, Aguilar CN. Biotechnological production of carotenoids by yeasts: an overview. Microb. Cell Fact. 2014;13:12.

[44] Wang C, Zhou F, Yang Z, Wang W, Yu F, Wu Y, et al. Hydrolysis of cellulose into reducing sugar via hot-compressed ethanol/water mixture. Biomass and Bioenergy 2012;42:143-50.

[45] Parajó JC, Santos V, Vázquez M, Cruz JM. Production of carotenoids by Xanthophyllomyces dendrorhous growing on enzymatic hydrolysates of prehydrolysed wood. Food Chem. 1997;

[46] Jirasripongpun K, Pewlong W, Natsathmonthra W, Suthiyaporn S. Carotenoids Production by Xanthophyllomyces dendrorhous Mutant Grown on Molasses. Kasetsart J. Nat. Sci. 2007;041:667-74.

[47] Ramírez J, Obledo N, Arellano M, Herrera E. Astaxanthin production by Phaffia rhodozyma in a fedbatch culture using a low cost medium feeding. e-Gnosis 2006;4:0-9.

[48] Yin C, Yang S, Liu X, Yan H. Efficient extraction of astaxanthin from phaffia rhodozyma with polar and non-polar solvents after acid washing. Chinese J. Chem. Eng. 2013;21:77680 .

[49] Blasko A, Belagyi J, Dergez T, Deli J, Papp G, Papp T, et al. Effect of polar and non-polar carotenoids on Xanthophylomyces dendrorhous membranes by EPR. Eur. Biophys. J. 2008;37:1097-104.

[50] Amaro HM, Fernandes F, Valentão P, Andrade PB, Sousa-Pinto I, Malcata FX, et al. Effect of Solvent System on Extractability of Lipidic Components of Scenedesmus obliquus (M2-1) and Gloeothece sp. on Antioxidant Scavenging Capacity Thereof. Mar. Drugs 2015;13:645371.

[51] Halim R, Danquah MK, Webley PA. Extraction of oil from microalgae for biodiesel production: A review. Biotechnol. Adv. 2012;30:709-32.

[52] Duarte SH, Santos P dos, Michelon M, Oliveira SM de P, Martínez J, Maugeri F. Recovery of yeast lipids using different cell disruption techniques and supercritical $\mathrm{CO} 2$ extraction. Biochem. Eng. J. 2017;125:230-7.

[53] Lopes NA, Remedi RD, dos Santos Sá C, Burkert CAV, de Medeiros Burkert JF. Different cell disruption methods for obtaining carotenoids by Sporodiobolus pararoseus and Rhodothorula mucilaginosa. Food Sci. Biotechnol. 2017;26:759-66.

[54] Sun S, Wen J, Sun S, Sun RC. Systematic evaluation of the degraded products evolved from the hydrothermal pretreatment of sweet sorghum stems. Biotechnol Biofuel 2015; 8: 37. 


\section{$1 \quad$ Tables}

2

Table 1: Details of the industrial enzymes used in the study

\begin{tabular}{|c|c|c|c|c|c|}
\hline Enzyme & Source & Main Activity & Side activities & Activity & $\begin{array}{l}\text { Stabiliser/ } \\
\text { Protectant }\end{array}$ \\
\hline Viscozyme ${ }^{\circledR} \mathbf{L}$ & $\begin{array}{l}\text { Aspergillus } \\
\text { aculeatus }\end{array}$ & Endoglucanse & $\begin{array}{l}\text { Xylanase } \\
\text { Cellulase }\end{array}$ & $100 \mathrm{FBG} / \mathrm{g}$ & Sucrose, $\mathrm{NaCl}$ \\
\hline Cellulase & $\begin{array}{c}\text { Aspergillus } \\
\text { niger }\end{array}$ & Endo-glucanase & - & $\sim 0.8$ unit $/ \mathrm{mg}$ & Not given \\
\hline Pectinase & $\begin{array}{l}\text { Aspergillus } \\
\text { aculeatus }\end{array}$ & Polygalacturonase & $\begin{array}{l}\text { Cellulase, } \beta \text { - } \\
\text { Galactosidase }\end{array}$ & $\geq 3800 \mathrm{unit} / \mathrm{ml}$ & Glycerol \\
\hline $\begin{array}{c}\text { Accellerase }{ }^{\circledR} \\
1500\end{array}$ & $\begin{array}{c}\text { Trichoderma } \\
\text { reesei }\end{array}$ & $\begin{array}{c}\text { Exoglucanase, } \\
\text { Endoglucanase and } \beta- \\
\text { Glucosidase }\end{array}$ & Hemicellulases & $\begin{array}{l}2200-2800 \\
\text { CMC unit/g }\end{array}$ & Not given \\
\hline
\end{tabular}

4 


\begin{tabular}{|c|c|}
\hline Composition & Percentage $(\%, w / w)$ \\
\hline Oil & $16.7 \pm 0.1$ \\
\hline Protein & $25.3 \pm 0.2$ \\
\hline Lignin & $18.0 \pm 4.6$ \\
\hline Ash & $5.3 \pm 0.1$ \\
\hline Moisture & $6.8 \pm 0.1$ \\
\hline Sugars (\% carbohydrate) & $34.2 \pm 6.2$ \\
\hline Glucose & $20.2 \pm 2.3$ \\
\hline Galactose & $2.9 \pm 0.5$ \\
\hline Arabinose & $5.9 \pm 0.7$ \\
\hline Xylose & $1.6 \pm 0.2$ \\
\hline Fructose & $0.3 \pm 0.2$ \\
\hline Fucose & $0.2 \pm 0.1$ \\
\hline Glucoronic acid & $0.4 \pm 0.3$ \\
\hline Galacturonic acid & $2.8 \pm 0.1$ \\
\hline
\end{tabular}

2 
1 Table 3: Effect of thermal pre-treatment (at $126^{\circ} \mathrm{C}$ and $135^{\circ} \mathrm{C}$ ) of rapeseed meal suspension $(10 \%$, $2 \mathrm{w} / \mathrm{v})$ followed by $15 \%(\mathrm{v} / \mathrm{v})$ of Accellerase 1500 treatment for $24 \mathrm{~h}$ on hydrolysis yield and sugar 3 concentrations

4

\begin{tabular}{|c|c|c|c|c|c|c|c|}
\hline \multirow[t]{2}{*}{$\begin{array}{c}\text { Temperature } \\
\left(\mathbf{T}^{\circ} \mathbf{C}\right)\end{array}$} & \multirow[t]{2}{*}{$\begin{array}{l}\text { Time } \\
(\min )\end{array}$} & \multicolumn{4}{|c|}{ Hydrolysis Yield (\%) } & \multicolumn{2}{|c|}{ Concentration $(\mathrm{g} / \mathrm{l})$} \\
\hline & & Glu & Xyl & Gal & Glu & Xyl & Gal \\
\hline $\begin{array}{r}\text { Control } \\
\text { (no pre-treatn }\end{array}$ & ent) & $29.82(0.31)^{\mathrm{a}}$ & $19.82(0.36)^{\mathrm{a}}$ & $79.28(1.43)^{\mathrm{a}}$ & $6.01(0.06)^{\mathrm{a}}$ & $0.95(0.02)^{\mathrm{a}}$ & $3.81(0.07)^{\mathrm{a}}$ \\
\hline 126 & 15 & $37.37(0.22)^{\mathrm{cd}}$ & $15.59(0.32)^{\mathrm{a}}$ & $62.37(1.27)^{\mathrm{a}}$ & $7.54(0.04)^{\mathrm{cd}}$ & $0.74(0.02)^{\mathrm{a}}$ & $2.97(0.06)^{\mathrm{a}}$ \\
\hline 126 & 30 & $40.44(2.12)^{\mathrm{bc}}$ & $16.97(0.82)^{\mathrm{b}}$ & $67.88(3.27)^{\mathrm{b}}$ & $8.15(0.43)^{\mathrm{bc}}$ & $0.81(0.04)^{\mathrm{b}}$ & $3.24(0.16)^{b}$ \\
\hline 126 & 60 & $34.25(0.15)^{\mathrm{c}}$ & $16.67(0.09)^{\mathrm{b}}$ & $66.69(0.36)^{\mathrm{b}}$ & $6.91(0.03)^{\mathrm{c}}$ & $0.79(0.01)^{b}$ & $3.18(0.02)^{b}$ \\
\hline 135 & 15 & $38.06(0.66)^{\mathrm{b}}$ & $16.74(0.33)^{\mathrm{b}}$ & $66.95(1.32)^{\mathrm{b}}$ & $7.67(0.13)^{\mathrm{b}}$ & $0.80(0.02)^{\mathrm{b}}$ & $3.19(0.06)^{b}$ \\
\hline 135 & 30 & $38.46(0.31)^{\mathrm{b}}$ & $15.72(0.16)^{\mathrm{a}}$ & $62.89(0.63)^{\mathrm{a}}$ & $7.75(0.03)^{\mathrm{b}}$ & $0.75(0.01)^{\mathrm{b}}$ & $3.00(0.01)^{b}$ \\
\hline
\end{tabular}




\begin{tabular}{|c|c|c|c|c|c|c|}
\hline $\begin{array}{l}\text { Rapeseed meal } \\
\text { hydrolysates }\end{array}$ & $\begin{array}{c}\text { Time } \\
\text { (h) }\end{array}$ & $\begin{array}{c}\text { Biomass } \\
(\mathrm{g} / \mathrm{l})\end{array}$ & $\begin{array}{c}P \\
(\mathbf{m g} / \mathbf{l})\end{array}$ & $\begin{array}{c}\mathbf{Y}_{\mathbf{P} / \mathbf{X}} \\
(\mu \mathrm{g} / \mathrm{g})\end{array}$ & $\begin{array}{l}Y \mathbf{X} / \mathrm{s} \\
(\mathrm{g} / \mathrm{g})\end{array}$ & $\underset{(\mathrm{g} / \mathrm{l})}{\mathbf{E t O H}_{\max }}$ \\
\hline Viscozyme ${ }^{\circledR} \mathbf{L}$ & 115 & $3.07 \pm 0.07$ & $0.4 \pm 0.03$ & $156 \pm 11.75$ & $0.07 \pm 0.02$ & $3.8 \pm 0.13$ \\
\hline Cellulase & 115 & $14.63 \pm 0.64$ & $1.10 \pm 0.18$ & $71 \pm 11.4$ & $0.25 \pm 0.01$ & $6.92 \pm 0.00$ \\
\hline Pectinase & 120 & $25.83 \pm 1.52$ & $6.71 \pm 0.44$ & $258 \pm 1.83$ & $0.46 \pm 0.03$ & - \\
\hline Accellerase ${ }^{\circledR} 1500$ & 118 & $8.2 \pm 0.01$ & $2.69 \pm 0.05$ & $332 \pm 12$ & $0.84 \pm 0.01$ & $2.02 \pm 0.15$ \\
\hline $\begin{array}{l}\text { Thermal treated plus } \\
\text { Accellerase } ₫ 1500\end{array}$ & 140 & $11.95 \pm 0.35$ & $3.2 \pm 0.4$ & $271 \pm 26.4$ & $0.81 \pm 0.05$ & $0.5 \pm 0.01$ \\
\hline
\end{tabular}

Y $_{\mathrm{P} / \mathrm{S}}$ : Yield of astaxanthin on substrate used.EtOH $\mathrm{max}_{\max }$ : Maximum ethanol concentration produced during the fermentation

$X$ : Dry cell weight 
Table 5: Fermentation data of X. dendrorhous in batch bioreactor cultures of rapeseed meal hydrolysates and semi-defined media

hyrolysates and semi-defined media

\begin{tabular}{|c|c|c|c|c|c|c|}
\hline Hydrolysates & $\begin{array}{c}\text { Time } \\
\text { (h) }\end{array}$ & $\begin{array}{c}\text { Total carbon } \\
\text { concentration } \\
(\mathrm{g} / \mathrm{l})\end{array}$ & $\begin{array}{c}X \\
(\mathrm{~g} / \mathrm{l})\end{array}$ & $\begin{array}{c}P \\
(\mathrm{mg} / \mathrm{l})\end{array}$ & $\begin{array}{c}Y_{\mathrm{p} / \mathbf{x}} \\
(\mu \mathrm{g} / \mathrm{g})\end{array}$ & $\begin{array}{l}Y_{\mathrm{X} / \mathrm{s}} \\
(\mathrm{g} / \mathrm{g})\end{array}$ \\
\hline $\begin{array}{c}\text { RSM+10\% } \\
\text { Accellerase } ®\end{array}$ & 112 & $17.66 \pm 0.2$ & $14.3 \pm 0.9$ & $3.6 \pm 0.1$ & $251 \pm 5$ & $0.81 \pm 0.05$ \\
\hline $\begin{array}{c}\text { RSM + } 10 \% \\
\text { Pectinase }\end{array}$ & 113 & $72.1 \pm 4.3$ & $42.0 \pm 0.4$ & $10.2 \pm 0.2$ & $242 \pm 6$ & $0.58 \pm 0.06$ \\
\hline $\begin{array}{c}\text { Semi }- \text { defined } \\
\text { media } \\
(30 \text { g/l glucose })\end{array}$ & 123 & $27.6 \pm 1.1$ & $16.3 \pm 0.4$ & $3.6 \pm 0.1$ & $221 \pm 8$ & $0.59 \pm 0.01$ \\
\hline
\end{tabular}

*Fermentation conditions: agitation, $1 \mathrm{l} / \mathrm{min}$; temperature, $20{ }^{\circ} \mathrm{C} ; \mathrm{pH}$ 6; agitation, $600 \mathrm{rpm}$

$\mathrm{Y}_{\mathrm{P} / \mathrm{X}}$ : Yield of astaxanthin on biomass produced.

$\mathrm{Y}_{\mathrm{P} / \mathrm{s}}$ : Yield of astaxanthin on substrate used.EtOH $\mathrm{max}_{\max }$ : Maximum ethanol concentration produced during the fermentation

$P$ : Astaxanthin production

10

$\mathrm{X}$ : Dry cell weight

11

12

13

14

15

16

17

18 
Table 6: Solubility of astaxanthin in solvents after incubation for $24 \mathrm{~h}$ at $25^{\circ} \mathrm{C}$.

\begin{tabular}{cc}
\hline Solvent & Concentration $(\mathrm{mg} / \mathrm{ml})$ \\
\hline Water & 0 \\
Ethanol & $0.038 \pm 0.004^{\mathrm{a}}$ \\
Acetone & $0.55 \pm 0.02^{\mathrm{b}}$ \\
Methanol & $0.04 \pm 0.002^{\mathrm{a}}$ \\
Dimethyl Sulfoxide (DMSO) & $1.64 \pm 0.03^{\mathrm{c}}$ \\
& $2.03 \pm 0.04^{\mathrm{d}}$
\end{tabular}

4 Different letters represent significant difference between solvents by Tukey pairwise comparison 5 $(p<0.05)$. 
Figures

4

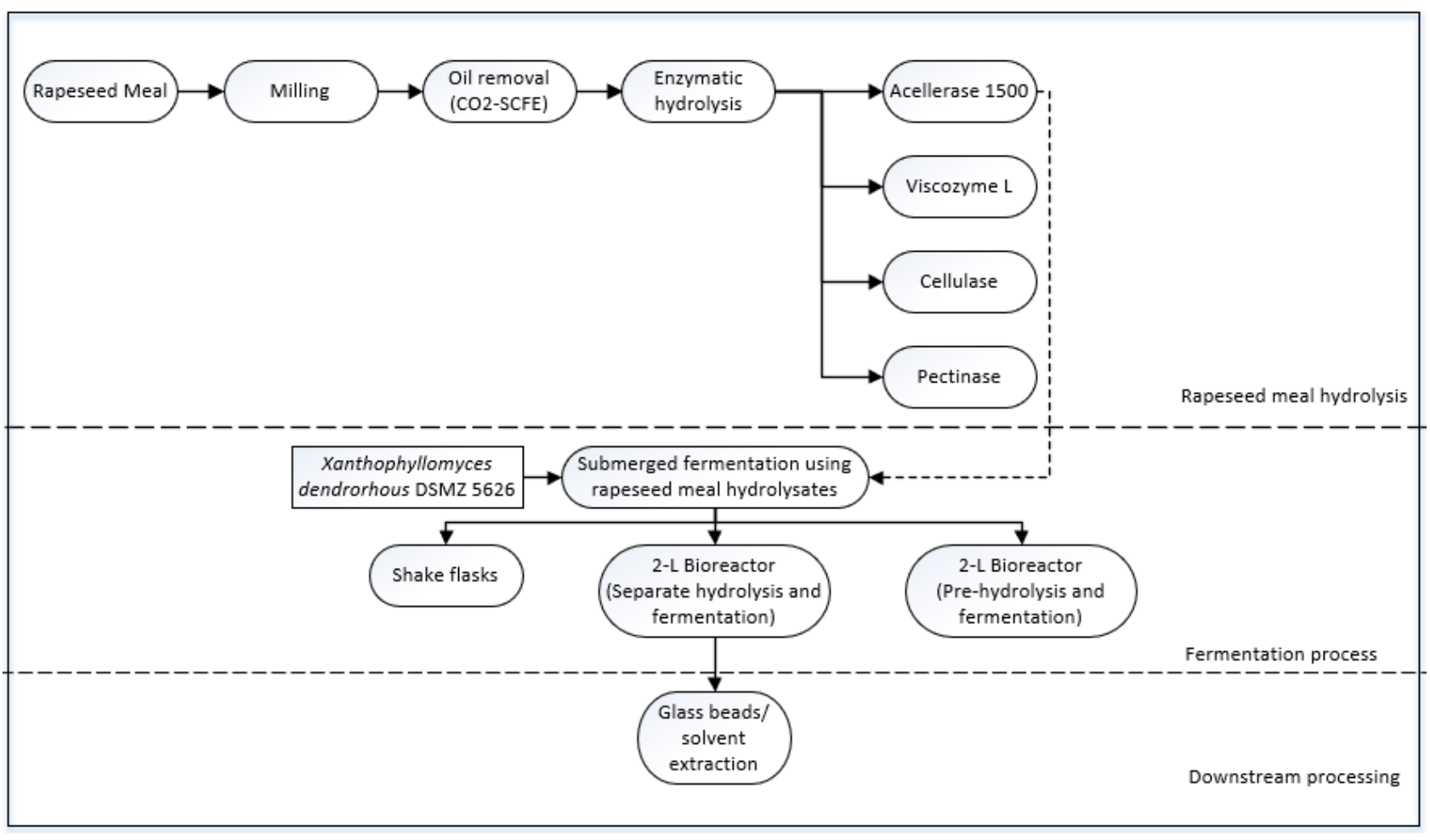

Figure 1: Schematic diagram of experimental procedure for astaxanthin production from rapeseed 7 meal in X. dendrorhous. 

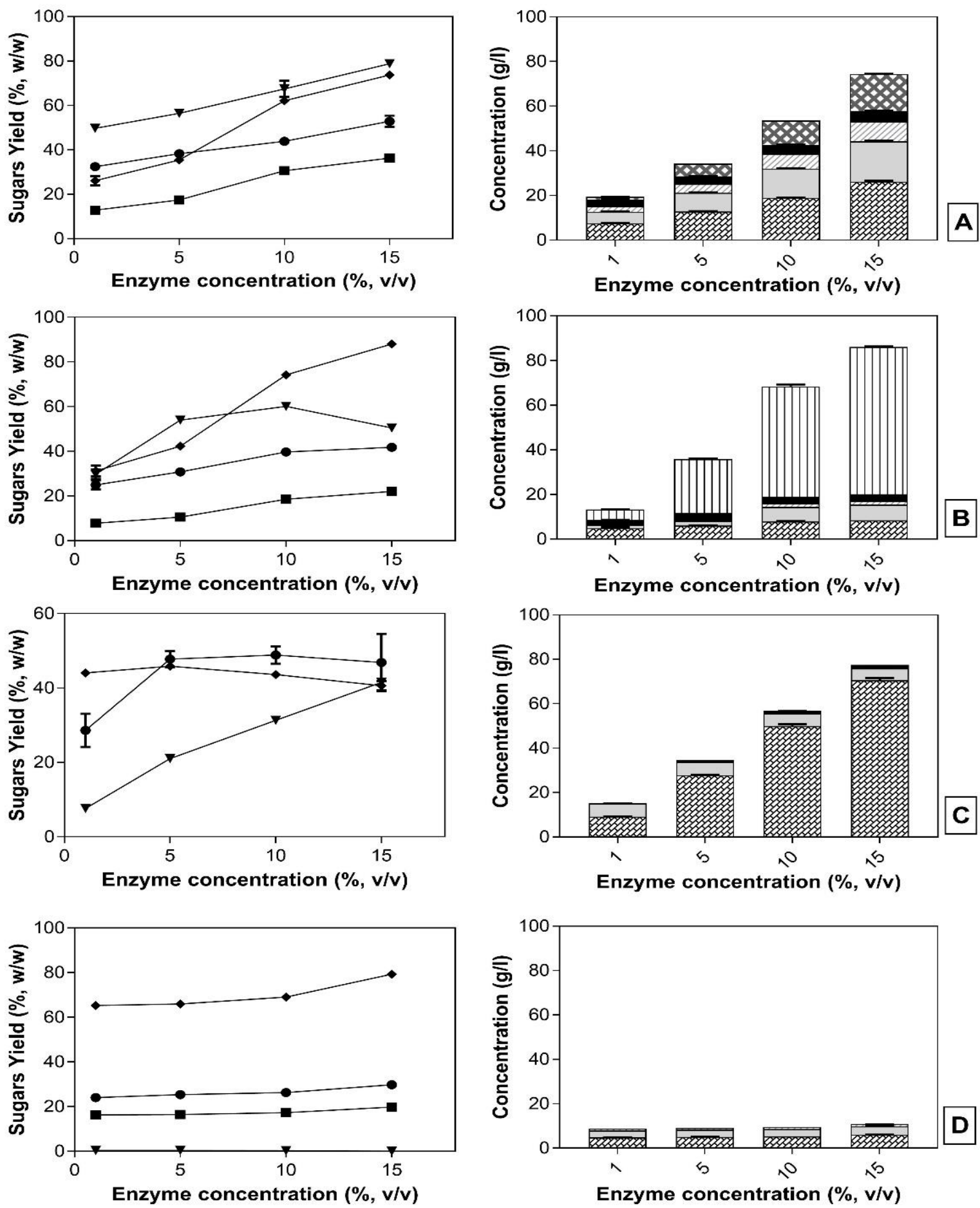

Figure 2: Effect of different enzyme concentrations on the total sugars released after 24 hrs of hydrolysis of $10 \%(w / v)$ rapeseed meal using commercial enzymes [Viscozyme ${ }^{\circledR}(A)$, pectinase $(B)$, cellulase $(C)$ and Accellerase $\left.{ }^{\circledR} 1500(D)\right]$. Line graph represents the sugars yield (\%), whereas the bar graph represents the concentration of sugars in rapeseed meal hydrolysates.

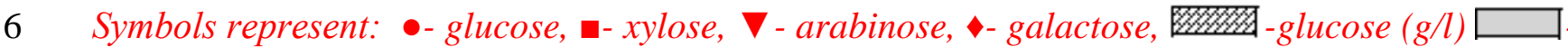



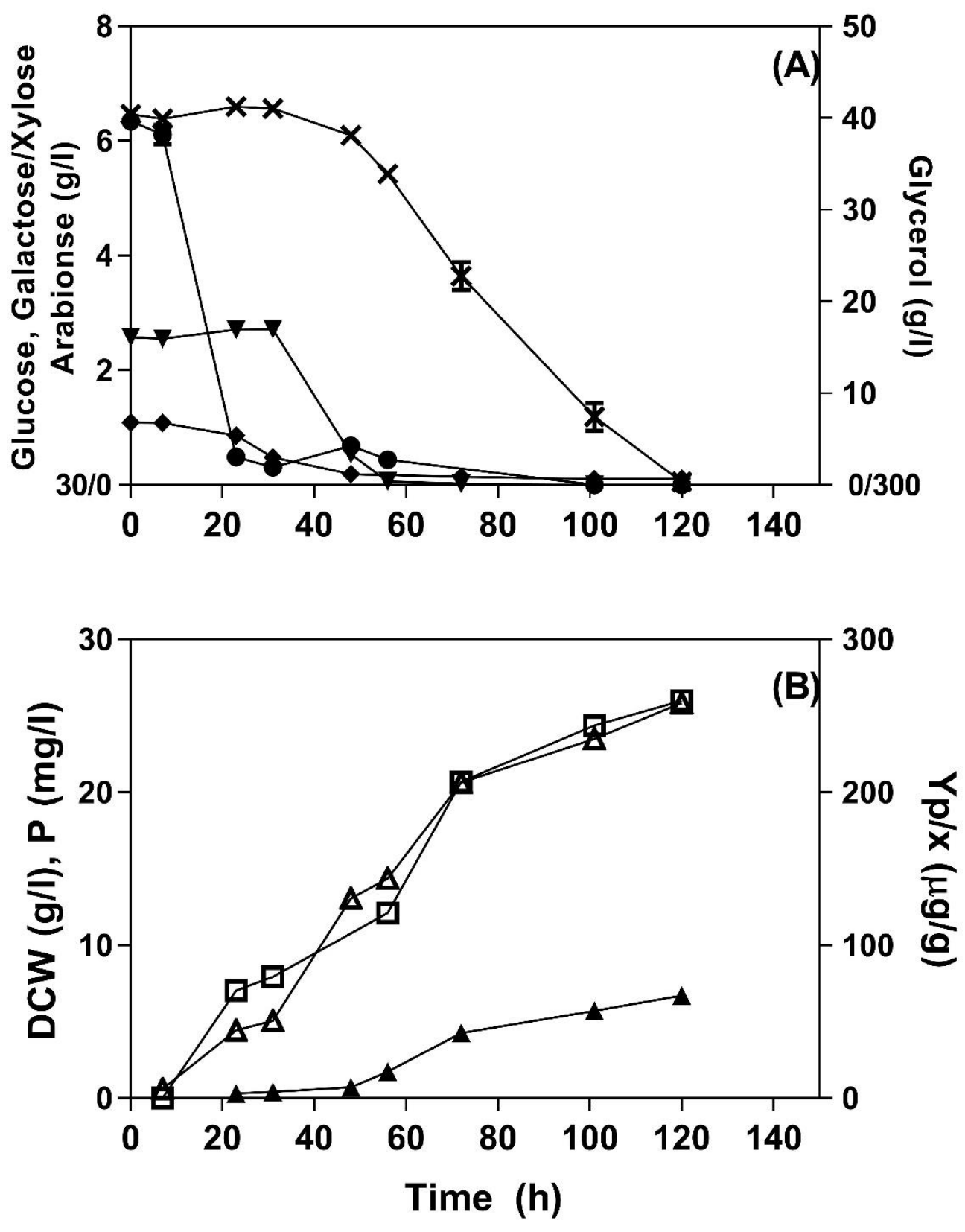

Figure 3:Kinetic profile of $(A)$ carbon sources consumption and $(B)$ product formation during X. dendrorhous growth in pectinase rapeseed meal hydrolysate in shake flasks. $g / l)$, yield of astaxanthin on biomass, $Y p / x(\square, \mu g / g)$, astaxanthin production $P(\mathbf{\Delta}, m g / l)$, dry cell weight $(\Delta, g / l)$. 


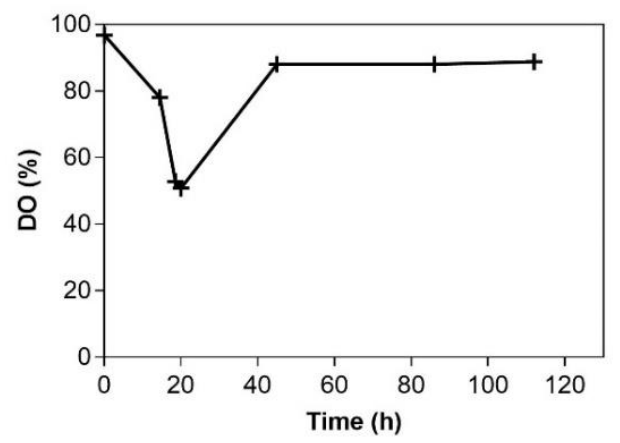

(A)

(B)
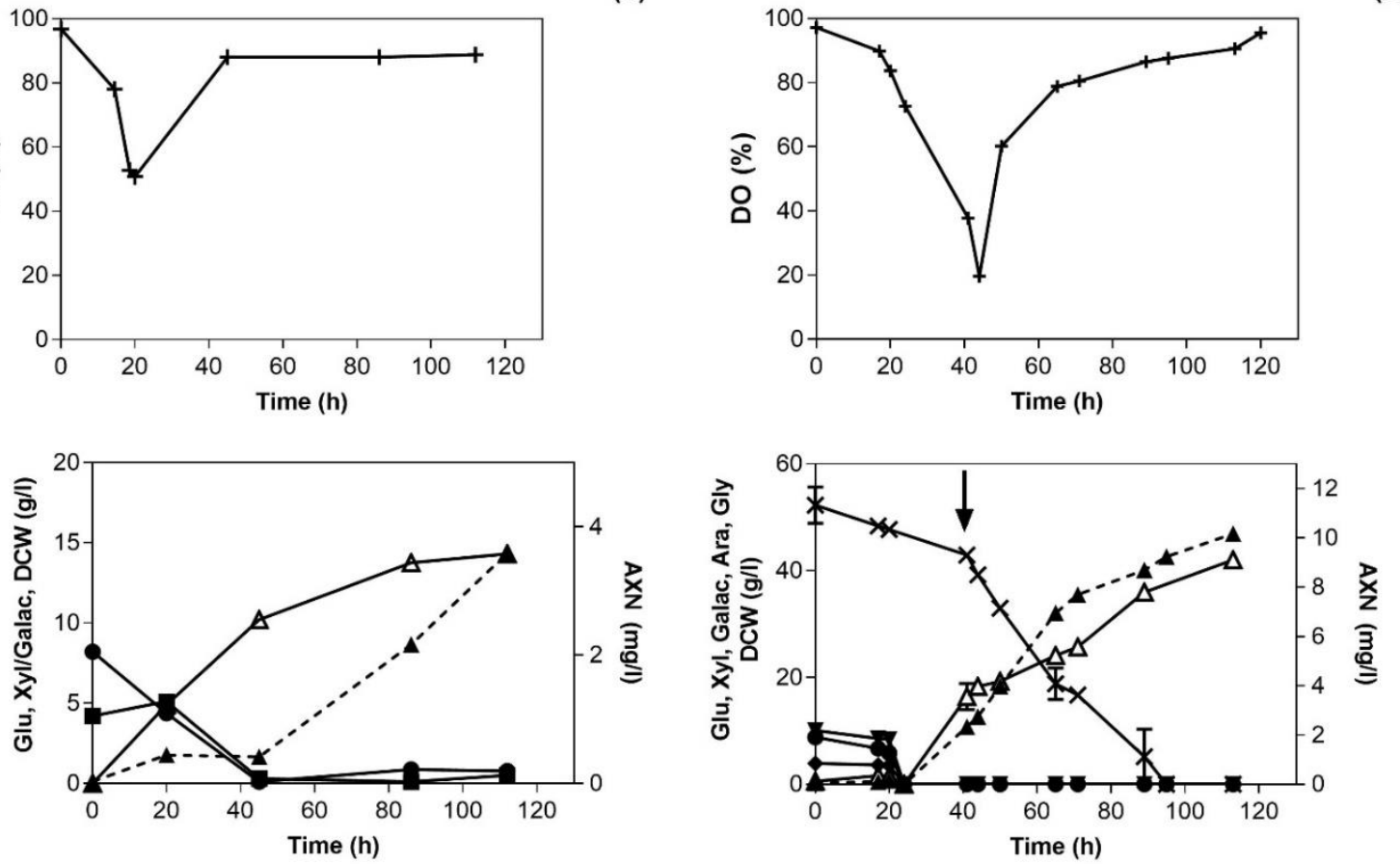

Figure 4: Growth profile of X. dendrorhous cultivated in 2-L stirred tank bioreactor with rapeseed meal hydrolysates as sole fermentation substrate with separate hydrolysis and fermentation strategy. A) Accellerase ${ }^{\circledR} 1500$ treated hydrolysates (15\% v/v of enzyme and $10 \% \mathrm{w} / \mathrm{v}$ of substrate); B) pectinase treated rapeseed meal hydrolysates $(10 \% \mathrm{v} / \mathrm{v}$ of enzyme and $10 \% \mathrm{w} / \mathrm{v}$ of substrate).

Fermentation conditions: aeration, $1 \mathrm{l} / \mathrm{min}$; temperature, $20^{\circ} \mathrm{C}$; $\mathrm{pH} 6$.

10 Symbols represent: - astaxanthin, $A X N(\boldsymbol{\Delta}, \mu \mathrm{g} / \mathrm{ml})$; glucose, Glu $(\bullet, \mathrm{g} / \mathrm{l}) ;$ xylosel galactose, Xyl, $11 \operatorname{Galac}(\boldsymbol{\nabla}, g / l)$, arabinose, Ara $(\diamond, g / l)$; dry cell weight, $D C W(\Delta, g /)$; glycerol, Gly $(\times, g / l)$; 

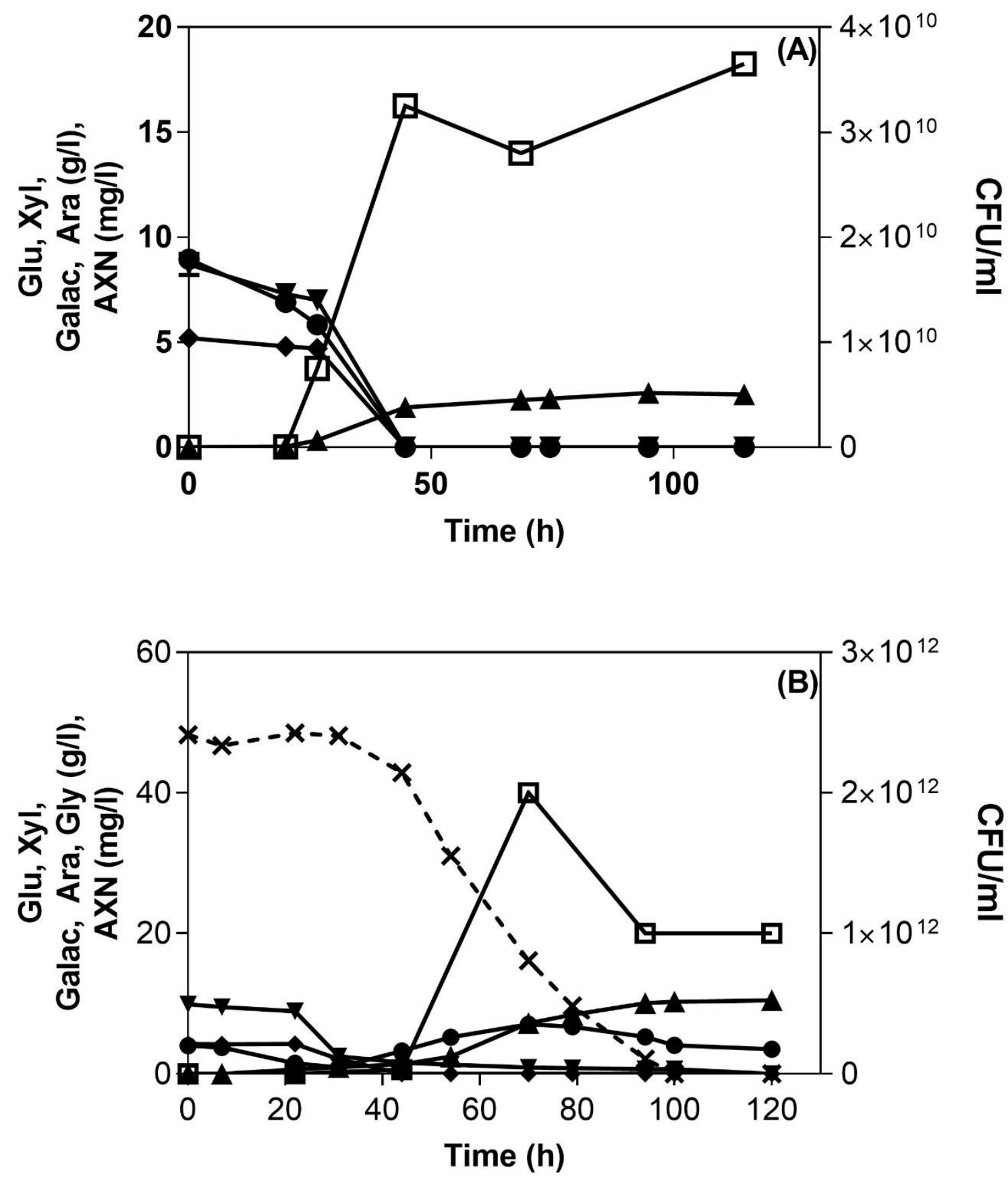

2 Figure 5: Growth profile of X. dendrorhous using prehydrolysis and fermentation approach. (A) $310 \%(\mathrm{v} / \mathrm{v})$ Accellerase ${ }^{\circledR}\left({ }^{\circledR}\right.$ Accellerase ${ }^{\circledR} \AA 1500$ in $10 \%(\mathrm{w} / \mathrm{v})$ substrate; $(B) 10 \%(\mathrm{v} / \mathrm{v})$ pectinase in 4 $10 \%(w / v)$ substrate Hydrolysis conditions: agitation, $250 \mathrm{rpm}$; temperature, $50^{\circ} \mathrm{C}$; time, $24 \mathrm{~h}$ Fermentation conditions: aeration, $1 \mathrm{l} / \mathrm{min}$; agitation, $600 \mathrm{rpm}$; temperature, $20{ }^{\circ} \mathrm{C}$; $\mathrm{pH} 6$

7 Symbols represent: - astaxanthin, $\operatorname{AXN}(\mathbf{\Delta}, \mu \mathrm{g} / \mathrm{ml}) ;$ glucose, Glu $(\bullet, \mathrm{g} / \mathrm{l}) ;$ xylosel galactose, Xyl, 8 Galac ( $\boldsymbol{\nabla}, g / l) ;$ glycerol, Gly $(\times, g / l) ; C F U(\square, C F U / m l)$ 


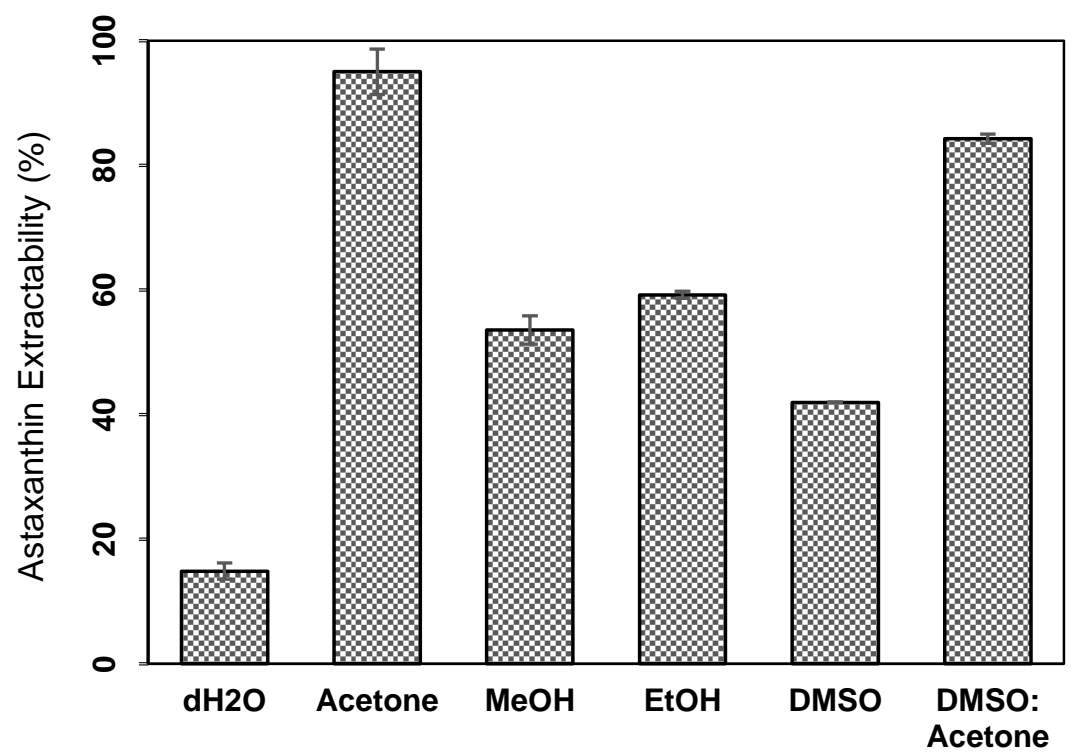

$3 \quad$ Figure 6: Percentage of astaxanthin extractability (\%) using glass beads (0.3 g) with different types 4 of solvents. Extraction was performed at room temperature under agitation at $2000 \mathrm{rpm}$

5 Different letters show the significant difference between each treatment using Tukey pairwise 6 comparison $(p<0.05)$.

Abbreviations: $\mathrm{dH}_{2} \mathrm{O}$ (distilled water), $\mathrm{MeOH}$ (methanol), EtOH (ethanol), DMSO (dimethyl sulfoxide)

9

10

11

12 


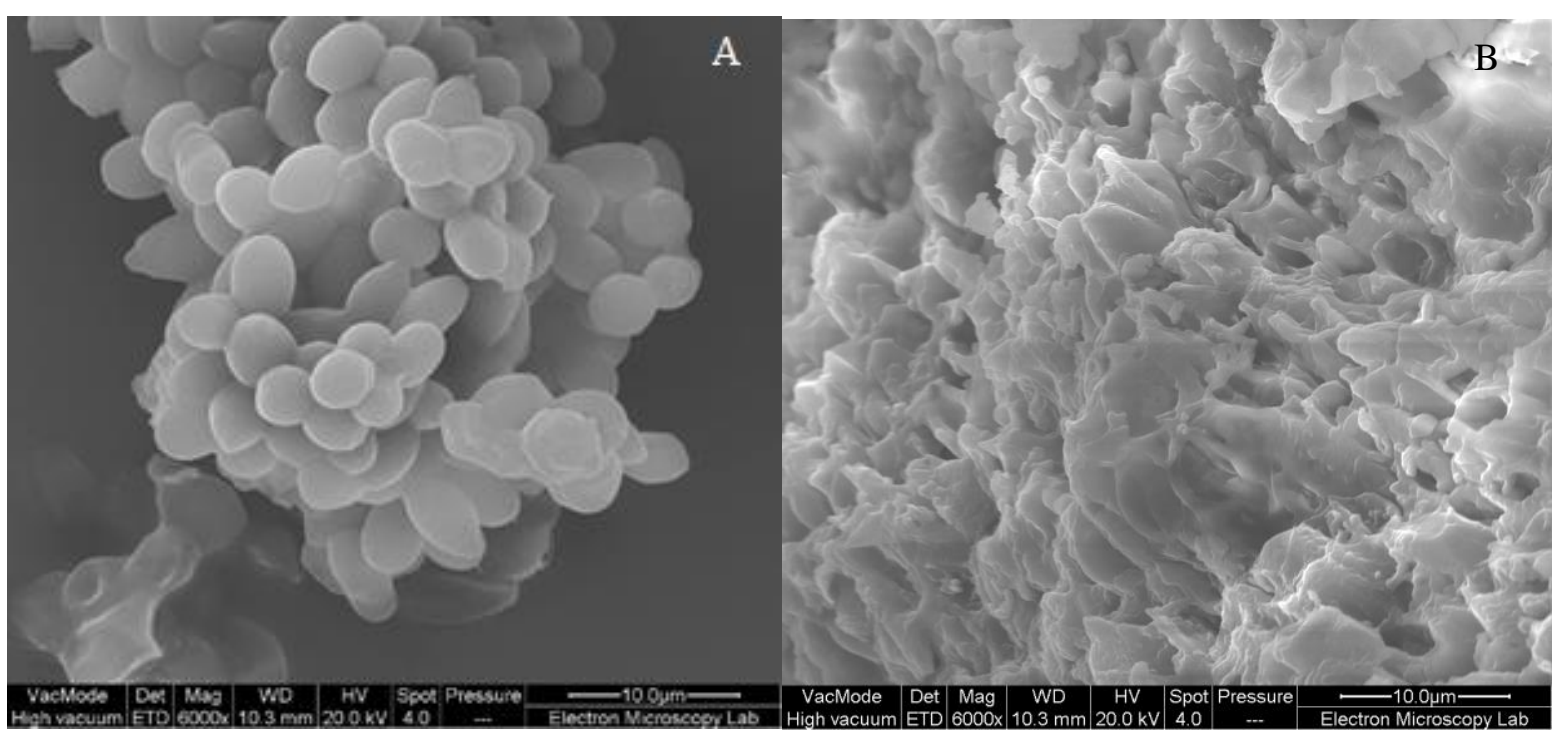

$3 \quad$ Figure 7: Scanning electron microscopy images X. dendrorhous cells A) intact cells, B) cells after 4 treatment with glass beads $(0.3 \mathrm{~g})$ followed by acetone $(100 \%)$ extraction. 